\title{
Plankton food-web functioning in anthropogenically impacted coastal waters (SW Mediterranean Sea): an ecological network analysis
}

\author{
Meddeb Marouan ${ }^{1,{ }^{*}}$, Grami Boutheïna ${ }^{2}$, Chaalali Aurelie ${ }^{3,4,5}$, Haraldsson Matilda $^{3}$, Niquil Nathalie ${ }^{3}$, \\ Pringault Olivier ${ }^{6}$, Hlaili Asma Sakka ${ }^{1}$
}

${ }^{1}$ Laboratoire de phytoplanctonologie, Faculté des Sciences de Bizerte, Université de Carthage, 7021

Zarzouna, Bizerte, Tunisie

${ }^{2}$ Laboratoire de Recherche "Bioressources: Biologie Intégrative \& Valorisation" BIOLIVAL, Institut

Supérieur de Biotechnologie de Monastir, Université de Monastir, Avenue Taher Hadad, 5000, Tunisie

${ }^{3}$ Normandie Université UNICAEN, UMR BOREA (MNHN, UPMC, CNRS-7208, IRD-207), CS 14032,

Caen, France

${ }^{4}$ IFREMER, Ecology and models applied to fishery resources, Nantes, France

${ }^{5}$ ESE, Ecology and Ecosystem Health, Agrocampus Ouest, INRA, 35042 Rennes, France

${ }^{6}$ Institut de Recherche pour le Développement (IRD), MARBEC, Marine Biodiversity, Exploitation \& Conservation, BP 4341004 Tunis, Tunisie, UMR IRD ( $\left.n^{\circ} 248\right)$, Ifremer, Univ. Montpellier, CNRS ( ${ }^{\circ}$ 9190)

* Corresponding author : Marouan Meddeb, email address : marouan.meddeb@yahoo.fr

\begin{abstract}
:
The study is the first attempt to (i) model spring food webs in three SW Mediterranean ecosystems which are under different anthropogenic pressures and (ii) to project the consequence of this stress on their function. Linear inverse models were built using the Monte Carlo method coupled with Markov Chains to characterize the food-web status of the Lagoon, the Channel (inshore waters under high eutrophication and chemical contamination) and the Bay of Bizerte (offshore waters under less anthropogenic pressure). Ecological network analysis was used for the description of structural and functional properties of each food web and for inter-ecosystem comparisons. Our results showed that more carbon was produced by phytoplankton in the inshore waters (966-1234 mg C m-2 d-1) compared to the Bay (727 mg C m-2 d-1). The total ecosystem carbon inputs into the three food webs was supported by high primary production, which was mainly due to $>10 \mu \mathrm{m}$ algae. However, the three carbon pathways were characterized by low detritivory and a high herbivory which was mainly assigned to protozooplankton. This latter was efficient in channelling biogenic carbon. In the Lagoon and the Channel, foods webs acted almost as a multivorous structure with a tendency towards herbivorous one, whereas in the Bay the herbivorous pathway was more dominant. Ecological indices revealed that the Lagoon and the Channel food webs/systems had high total system throughput and thus were more active than the Bay. The Bay food web, which had a high relative ascendency value, was more organized and specialized. This inter-ecosystem difference could be due to the varying levels of anthropogenic impact among sites. Indeed, the low value of Finn's cycling index indicated that the three systems are disturbed, but the Lagoon and the Channel, with low average path lengths, appeared to be
\end{abstract}


more stressed, as both sites have undergone higher chemical pollution and nutrient loading. This study shows that ecosystem models combined with ecological indices provide a powerful approach to detect change in environmental status and anthropogenic impacts.

\section{Highlights}

- Herbivorous and multivorous food-webs were the dominant carbon pathways in the Bay and the Lagoon/Channel, respectively during the study period. Indices used, showed that the Lagoon and the Channel seemed to be more stressed, more active, and less organized compared to the Bay of Bizerte. - Inverse modelling combined with ecological networks analysis may offer an effective tool for management and assessment of ecosystems health, and to diagnose the occurrence of anthropogenic pressures.

Keywords : Food-web modelling, Ecological Network Analysis, Mediterranean coastal waters, plankton ecology 


\section{Introduction}

Food webs are by definition simple representations of who eats whom in a considered ecosystem. The common representation of a pelagic food web from the 1920 s to the 1970 s consisted of a three level compartment: 1. algae as primary producers of organic matter, 2 . zooplankton (metazoa) as consumers of primary production (grazers), and 3. Ichthyoplankton (fish larvae) as predators (or secondary consumers). This three-level chain was called "herbivorous food chain" (Steele, 1974). With the discovery of the functional role of autotrophic and heterotrophic microorganisms as producers and consumers of organic matter (Pomeroy, 1974), the interactions between the organisms were represented in a more complex way. Azam et al. (1983) introduced the concept of the "microbial loop", which emphasized the importance of heterotrophic microbes in the transfer of organic carbon to larger consumers. Then, Sherr and Sherr (1988) suggested a new food-web structure called the "microbial food web" where autotrophic and heterotrophic microorganisms are dominant and sustain the functioning of the ecosystem. Legendre and Rassoulzadegan (1995) suggested complementarily a "multivorous food web" where herbivorous and microbial organisms co-act to transfer organic carbon to larger organisms. Legendre and Rivkin (2002) stressed that respiration and downward export of particulate and dissolved organic carbon could be a major way of biogenic carbon export out of the pelagic food web. More recently, food-web modelling approaches have enabled ecologists to describe new food-web structures such as: "phytomicrobial" where microzooplankton mostly graze on phytoplankton and "polymicrobial" where microzooplankton graze equally on all food resources (Sakka Hlaili et al., 2014). 
Food-web models summarize data obtained for any environment into a network of compartments connected by trophic links. Using any modelling approach, more integrated and concise information can be obtained on the functioning of pelagic ecosystems and compared with other modelled ecosystems. Ecosystem models provide a powerful approach to analyse and predict the consequence of environmental and anthropogenic pressures on food web structure and functioning. Several methods have been developed to characterize marine food webs. The Linear Inverse Model (LIM), as defined by Vézina and Platt (1988), allows the estimation of unknown trophic flows through the pelagic food web and alleviates the problem of under-sampling using the principle of the conservation of mass, i.e. the quantity of carbon coming into each compartment considered as equal to the amount leaving it. Moreover, this approach is considered as sufficient to describe the structure of aquatic ecosystems (Vézina and Pahlow, 2003; Savenkoff et al., 2004). It has been applied to a wide range of ecosystems: coastal areas (Vézina and Platt, 1988; Jackson and Eldridge, 1992), bays (Richardson et al., 2003; Marquis et al., 2007), lakes (Niquil et al., 2011), oceans (Vézina et al., 1997; Richardson et al., 2004) and gulfs (Vézina et al., 2000; Savenkoff et al., 2004; Chaalali et al., 2015). This deterministic method had limitations (e.g. Eldridge and Jackson, 1993; Niquil et al., 1998; Donali et al., 1999; Kones et al., 2006), and was therefore modified into the Monte Carlo Markov Chain Linear Inverse method (LIM-MCMC; Van den Meersche et al., 2009) based on a sampling procedure that attempts a complete coverage of the range of possible solutions. This new approach allows the estimation of likelihood distributions of the flows rather than unique estimates and also takes into account flow variability resulting from uncertainty in sampling data (Grami et al., 2011; Niquil et al., 2012; Rasconi et al., 2014; Saint-Béat et al., 2013; 2015; Chaalali et al., 2015; 2016; Tecchio et al., 2016).

Ecological Network Analysis (ENA) is a group of algorithms describing food-web structure and functioning using the output of the calculated flows given by the modelling exercise. 
ENA is based on a set of indices (i.e. the ENA indices) that describe (i) the connections between food-web compartments through an analysis of the input and output flows, (ii) the trophic structure, (iii) the topology, (iv) and the recycling in the network (Ulanowicz, 1996). When applied to the estimated flows of the food-web model, ENA allows qualitative and quantitative description of the ecosystem properties (Ulanowicz, 1986; Fath et al., 2007). This tool has been widely used in coastal ecology to characterize the food-web structure, the level of organization, the network dependence on external factors, and to evaluate the ecosystem stress level and its stability (Heymans et al., 2014; Saint-Béat et al., 2015).

Mediterranean coastal waters are currently under large anthropogenic pressure, leading to their eutrophication and chemical contamination (Bianchi et al., 2000; Boudouresque et al., 2002; Mzoughi et al., 2005; Sakka Hlaili et al., 2007; Sahraoui et al., 2012). Despite this, a few studies have addressed change in the structure and functioning of the food webs in some Mediterranean northern waters such as those in the Catalan continental slope (Tecchio et al., 2013) and the Gulf of Lions (Auger et al., 2011, Alekseenko et al., 2014). However, ecosystem-level studies in the South of the Mediterranean Sea are very scarce. Indeed, only one study using the LIM approach has modelled the plankton trophic pathways in the semi-enclosed Bizerte Lagoon (Grami et al., 2008), but studies on nearby marine ecosystems are non-existent. So, in the present study, we have applied the approach LIM-MCMC to characterize the trophic food-web status and its associated structural and functional properties in inshore (Lagoon and Channel of Bizerte) and offshore (Bay of Bizerte) coastal waters located in the south-west of the Mediterranean Sea. The work was carried out in these three ecosystems, which differ in environmental conditions and anthropogenic pressures, in order to evaluate if modelling allows us to identify the variability in the structure and the functioning of each planktonic food web. We specifically addressed the following questions: does planktonic food web function differently among these coastal waters during spring? Is their 
primary production efficiently channelled to higher trophic levels? What is the environmental status of each site with regard to productivity, trophic structure, carbon transfer, stress, and organisation levels?

The data of standing stocks (bacteria, phytoplankton, protozooplankton, and metazooplankton) and some in situ estimated carbon flows (bacterial and phytoplankton production, protozooplankton grazing and metazooplankton grazing) were described in Meddeb et al. (submitted). In the present study, we used these data in addition to a measure of Dissolved Organic Carbon (DOC) and Particulate Organic Carbon (POC) stocks and vertical carbon flowing in each ecosystem. All data were integrated in a common view of ecosystem functioning, and completed, using the inverse analysis LIM-MCMC.

\section{Material and Methods}

\subsection{Study sites}

Water sampling was carried out during spring 2012 in three south-western Mediterranean ecosystems, situated in the city of Bizerte (Tunisia, Fig. 1). The sites are the Lagoon (inshore station L: $37^{\circ} 12^{\prime} 46^{\prime \prime} \mathrm{N}, 09^{\circ} 50^{\prime} 48^{\prime \prime} \mathrm{E}$ ), the Channel (inshore station C: $37^{\circ} 15^{\prime} 04^{\prime \prime} \mathrm{N}, 9^{\circ} 52^{\prime} 34^{\prime \prime} \mathrm{E}$ ) and the Bay (offshore station B: $37^{\circ} 16^{\prime} 54^{\prime \prime}$ N, 9 $9^{\circ} 53^{\prime} 42^{\prime \prime}$ E) of Bizerte. The Lagoon, with a surface area of $121.6 \mathrm{~km}^{2}$ and a maximum depth of $12 \mathrm{~m}$, is a semi-enclosed ecosystem that receives a large amount of freshwater, particularly in winter, from several surrounding rivers and mainly from Lake Ichkeul (Fig. 1). The hydrodynamics are mainly driven by wind (Harzallah et al., 2003; Bejaoui et al., 2005). The lagoon is experiencing increasing nutrient concentrations (10.69-17.89 N $\mu \mathrm{M}, 0.86-1.33 \mathrm{P} \mu \mathrm{M}$ and 12.30-13.30 Si $\mu \mathrm{M}$, Sakka Hlaili et al., 2008) from expanding urban, agricultural, and industrial development, leading in turn to high Chl $a$ concentrations (4.43-5.48 $\mathrm{mg} \mathrm{m}^{-3}$, Sakka Hlaili et al., 2008). The anthropogenic activities lead to a contamination of the sediment of the lagoon by several pollutants, including heavy metals (as $\mathrm{Zn}, \mathrm{Cd}, \mathrm{Co}, \mathrm{Cu}, \mathrm{Pb}, \mathrm{Ni}, \mathrm{Cd}, \mathrm{Mn}$, and $\mathrm{Fe}, 20-598 \mu \mathrm{g} \mathrm{g}^{-1}$, Ben Mna 
et al., 2017), organotins (170 $\mathrm{ng} \mathrm{kg} \mathrm{kg}^{-1}$, Mzoughi et al., 2005), polycyclic aromatic hydrocarbons (PAHs: 3042-9948 ng g ${ }^{-1}$, Zmerli et al., 2017), and pesticides (1.1-14.0 ng g ${ }^{-}$ ${ }^{1}$ of dry sediment,Barhoumi et al., 2013). The Lagoon is one of the most economically important areas in Tunisia, sustaining large populations of planktivorous fish and shellfish (mussels, oysters, and clams). The Lagoon is connected northwards to the Mediterranean Sea through the Bizerte Channel (7 km long, $300 \mathrm{~m}$ wide, and $12 \mathrm{~m}$ deep). This site supports eutrophied waters $(34.40 \pm 12 \mathrm{~N} \mu \mathrm{M}, 1.30 \pm 0.3 \mathrm{P} \mu \mathrm{M}$ and $1.20 \pm 1.05 \mathrm{Si} \mu \mathrm{M}$, Sahraoui et al., 2012) with high Chl $a$ concentrations (6.20 $\pm 4 \mathrm{mg} \mathrm{m}^{-3}$, Sahraoui et al., 2012) and was significantly polluted by heavy metals (especially $\mathrm{Zn}, \mathrm{Cr}$, and $\mathrm{Pb}, 85-228 \mathrm{mg} \mathrm{g}^{-1}$ of dry sediment) and PAHs (21-772 $\mu \mathrm{g} \mathrm{g}^{-1}$ of dry sediment) (Pringault et al., 2016). The Bay of Bizerte, with a depth of $16-20 \mathrm{~m}$, is an open ecosystem directly connected to the Mediterranean Sea. This site supports lower levels of inorganic nutrients $(1.19 \pm 0.9 \mathrm{~N} \mu \mathrm{M}$, $0.53 \pm 0.02 \mathrm{Si} \mu \mathrm{M}$ and $<1 \mathrm{P} \mu \mathrm{M})$ and $\mathrm{Chl} a\left(0.5-2.5 \mathrm{mg} \mathrm{Chl} a \mathrm{~m}^{-3}\right)$ (Sahraoui et al., 2012), compared to the two other sites. It is also less contaminated than the Lagoon and the Channel. The PAHs (78 $\mu \mathrm{g} \mathrm{g}^{-1}$ of dry sediment, Boufahja, 2010) are the main pollutants, which are originated from the oil refinery located on the shore of the Bay (Zrafi-Nouira et al., 2008; Ben Ameur et al., 2013).

\subsection{Sampling and water analysis}

At each station, water was collected during spring 2012 at four depths using an acid-washed 2.5 L plastic water sampler (Hydro-Bios), which was then pre-filtered through a $200 \mu \mathrm{m}$ mesh net to remove meso- and macrozooplankton (except water used for DOC determination) before storing it in isothermal containers until processing. Five $\mathrm{mL}$ subsamples were filtered on sterilized $0.2 \mu \mathrm{m}$ polycarbonate filters and then frozen in acid-washed vials at $-20^{\circ} \mathrm{C}$ until analysis for dissolved organic carbon (Knap et al., 1993) using a Shimadzu TOC-5000 carbon analyser. Subsamples for determination of POC were filtered on pre-combusted (at $450^{\circ} \mathrm{C}$, 
during $2 \mathrm{~h}) \mathrm{GF} / \mathrm{F}$ Whatman filters $(21 \mathrm{~mm})$ and analysed on a CHN elemental analyser (Perkin-Elmer 2400), as described in the JGOFS report (Knap et al., 1996). Subsamples were also taken for plankton enumeration and identification.

For the heterotrophic bacteria (bac) count, $20 \mathrm{ml}$ samples were preserved with formaldehyde (final concentration of $4 \%$ ) and kept refrigerated at $4^{\circ} \mathrm{C}$. Each sample $(2 \mathrm{ml})$ was labelled with $0.2 \mathrm{ml}$ of a solution of orange acridine for 2 minutes (Hobbie et al., 1977; Parsons et al., $1984)$ and filtered under low pressure on a black filter $(0.22 \mu \mathrm{m}$, polycarbonate). Counting of bacteria was performed under a CETI Topic-T epifluorescence microscope using a 100x objective and the blue filter. The count was done in 20 random fields and by counting 400 cells per slide. To enumerate prokaryotic and eukaryotic picophytoplankton (pic), samples (10 $\mathrm{ml}$ ) were preserved in $0.22 \mathrm{~mm}$ prefiltered formaldehyde ( $2 \%$ final concentration) and stored for $1 \mathrm{~h}$ in darkness at $4^{\circ} \mathrm{C}$. The samples were then filtered on $0.22 \mathrm{~mm}$ black polycarbonate filters (Nuclepore), laid over $0.45 \mathrm{~mm}$ nitrocellulose backing filters (Millipore). The filters were mounted on slides using low-fluorescence immersion oil and stored immediately at $20^{\circ} \mathrm{C}$. Abundance was determined under a CETI Topic-T epifluorescence microscope $(100 \mathrm{x}$ Fluotar objective), as described in MacIsaac and Stockner (1993), using blue and green excitation and counting at least 200 cells from 30 random squares. Samples for identification and enumeration of phytoplankton [nanophytoplankton: 2-10 $\mu \mathrm{m}$ (nan) and microphytoplankton: 10-200 $\mu \mathrm{m}$ (mic)] and protozooplankton (pro: 5-200 $\mu \mathrm{m}$, composed of heterotrophic nanoflagellates, dinoflagellates, and ciliates) were fixed with $4 \%$ acid Lugol solution (Parsons et al., 1984) and 5\% alkaline Lugol solution (Sherr and Sherr, 1993), respectively. Cell abundances were determined under an inverted microscope (100 x objectives) on 50 or $100 \mathrm{ml}$ settled volumes (Lund et al., 1958). At least 200 cells in each sample were counted. 
Metazooplankton [two size classes: $200 \mu \mathrm{m}$ (met1) and $700 \mu \mathrm{m}$ (met2)] were sampled using two horizontal net tows with $200 \mu \mathrm{m}$ and $700 \mu \mathrm{m}$ mesh net. Samples were then preserved in borate-buffered formalin (5\% final concentration) for identification and counts of organisms, which were performed under a dissecting stereomicroscope (Leica).

\subsection{Areal carbon stocks}

The carbon biomasses of plankton were calculated as described in full details in Meddeb et al. (Submitted). Cell volumes $\left(\mu \mathrm{m}^{3}\right)$ of bacteria and picophytoplankton were converted to carbon content (pg C cell ${ }^{-1}$ ) using specific conversion factors (Table 1). For phytoplankton and protozooplankton, biovolumes were estimated by applying standard geometric formulae to each taxon, as proposed by Hillebrand et al. (1999). Then, the carbon content was obtained using specific conversion factors or formulae (Table 1). For mesozooplankton, the length and width of organisms were measured and were converted to carbon content using conversion factors or formulae corresponding to each taxonomic group (Table 1). The carbon biomasses of each plankton community (bac, pic, nan, mic, pro, met1, and met2) were estimated by multiplying their cell carbon by their corresponding abundances.

The concentration of dissolved organic carbon (doc) was obtained considering that $1 \mu \mathrm{M}$ of doc is equal to $12 \mathrm{mg} \mathrm{C} \mathrm{m}^{-3}$ (Grami et al., 2008). The detrital organic carbon (det) was estimated as total POC, determined from water column, minus the total carbon biomass of all plankton communities.

The final areal carbon stocks $\left(\mathrm{mg} \mathrm{C} \mathrm{m}^{-2}\right)$ were calculated by vertically integrating the carbon concentration ( $\mathrm{mg} \mathrm{C} \mathrm{m}^{-3}$ ) calculated from the sampling depths.

\subsection{Areal carbon flows}

\subsubsection{Production of bacteria and phytoplankton and their grazing by protozooplankton}

Dilution experiments were carried out at each site to estimate growth rates $\left(\mathrm{k}, \mathrm{d}^{-1}\right)$ of bacteria and size-fractionated phytoplankton (pic, nan, and mic), as well as their grazing rates $\left(\mathrm{g}, \mathrm{d}^{-1}\right)$ 
by protozooplankton (Landry and Hassett, 1982; Sakka Hlaili et al., 2007). Heterotrophic nanoflagellates (Leucocryptos sp.and Meringospheara spp.) and small aloricate ciliates (Strombidium spp.) were considered as main grazers of bacteria and pico/nanophytoplankton, while heterotrophic dinoflagellates (species of Gyrodinium, Gymnodinium, Ceratium, Alexandrium, and Protoperidinium) and tintinnids (Tintinnopsis corniger, Helicostemella kiliensis, and Parafavella gigantea) were assigned as major grazers of microphytoplankton. Details for experimental procedure and calculation are fully provided in Meddeb et al. (submitted). In brief, collected water at each sampling station was filtered on a $200 \mu \mathrm{m}$ mesh net to remove meso- and macrozooplankton. Very small metazoa $(<200 \mu \mathrm{m}$, such as copepods nauplii) were extremely rare in the samples and were therefore not considered in the dilution experiment. The $200 \mu \mathrm{m}$ filtered water was mixed with free-particle sea water to give four dilution factors $(100 \%, 75 \%, 50 \%$ and $25 \%$ of $<200 \mu \mathrm{m}$ prefiltered water). Each dilution mixture was then distributed into three clean 2-1 polycarbonate bottles, which were incubated at in situ temperature $\left(19-22^{\circ} \mathrm{C}\right)$ at the sampling depths for $24 \mathrm{~h}$. The estimated rates $\mathrm{k}$ and $\mathrm{g}$ were used to calculate gross production rates for phytoplankton and bacteria $\left(\mathrm{P}, \mathrm{mg} \mathrm{C} \mathrm{m}^{-3} \mathrm{~d}^{-1}\right)$

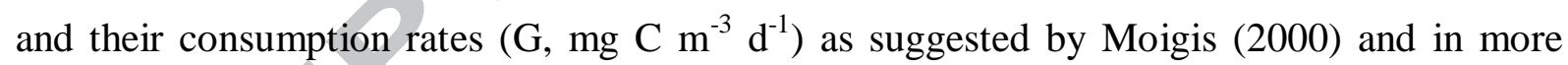
recent works(Sakka Hlaili et al., 2008, Grattepanche et al., 2011):

$$
\begin{aligned}
& P=\mathrm{kx} \mathrm{C}_{0}\left[\mathrm{e}^{(\mathrm{k}-\mathrm{g}) \mathrm{t}}-1\right] /(\mathrm{k}-\mathrm{g}) \times \mathrm{t} \\
& \mathrm{G}=\mathrm{g} \times \mathrm{C}_{0}\left[\mathrm{e}^{(\mathrm{k}-\mathrm{g}) \mathrm{t}}-1\right] /(\mathrm{k}-\mathrm{g}) \times \mathrm{t}
\end{aligned}
$$

where $\mathrm{C}_{0}\left(\mathrm{mg} \mathrm{C} \mathrm{m}^{-3}\right)$ is the initial biomass of phytoplanktonor bacteria, and $\mathrm{t}(\mathrm{d})$ is the incubation time $(1 \mathrm{~d})$.

Values of $\mathrm{P}$ and $\mathrm{G}$ from the four sampling depths were integrated to determine the areal rates (mg C m $\mathrm{m}^{-2} \mathrm{~d}^{-1}$ ) of production and consumption.

\subsubsection{Grazing of phytoplankton by metazooplankton}


Grazing impact of mesoplanktonic metazoa was assessed by the gut fluorescence method (Mackas and Bohrer, 1976; Slaughter et al., 2006). Since mesozooplankton are known to have inefficient feeding on $<5 \mu \mathrm{m}$ prey (Berggreen et al., 1988; Morales et al., 1993), we have assumed that they can only consume the nano- and microphytopalnkton in our study. The description of the experiment procedure and calculations have been detailed in Meddeb et al. (submitted). In brief, vertical sampling of mesozooplankton was undertaken from bottom to surface in each site using $200 \mu \mathrm{m}$ and $700 \mu \mathrm{m}$ mesh net. This allowed the calculation of phytoplankton grazing by two size fractions of metazoa $(200-700 \mu \mathrm{m}$ and $>700 \mu \mathrm{m})$. Subsamples (0.5 or 1 l) were filtered onto $47 \mathrm{~mm}$ GF/F filters, homogenized in $90 \%$ acetone using a motorized tissue homogenizer, and filtered through $25 \mathrm{~mm} \mathrm{GF/F}$ filters to remove pulp. The filtrates containing extracted gut pigment were measured before and after acidification with $10 \%$ hydrochloric acid using the spectrophotometric method of Lorenzen (1967).

Gut pigment content (GP, mg pigment $\mathrm{m}^{-3}$ ) was calculated using the following equation:

$$
\mathrm{GP}=\left(\mathrm{GP}_{\text {sub }} \times \mathrm{v}\right) /\left(\mathrm{F} \times \mathrm{V}_{\text {net }}\right)
$$

where, $\mathrm{GP}_{\text {sub }}$ is the gut pigment concentration $\left(\mathrm{mg}\right.$ pigment $\left.\mathrm{m}^{-3}\right)$ from the subsample, $\mathrm{v}\left(\mathrm{m}^{3}\right)$ is the volume of the subsample, $\mathrm{F}$ is the fraction of subsample processed for gut pigment content, and $\mathrm{V}_{\text {net }}\left(\mathrm{m}^{3}\right)$ is the total volume of water filtered during each net tow.

Metazooplankton grazing rate $\left(\mathrm{GM}, \mathrm{mg} \mathrm{C} \mathrm{m}^{-3} \mathrm{~d}^{-1}\right)$ was calculated as:

$$
\mathrm{GM}=\mathrm{GP} \times \mathrm{WC} \times \mathrm{C}: \mathrm{Chl} a
$$

where GP (mg pigment $\mathrm{m}^{-3}$ ) is the concentration of gut pigment, $\mathrm{C}: \mathrm{Chl} a$ is the depth-averaged C:Chl $a$ ratio determined for $>2 \mu \mathrm{m}$ phytoplankton (i.e. nano- and microphytoplankton) at each station, and $\mathrm{WC}\left(\mathrm{d}^{-1}\right)$ is the portion of water cleared per day.

Finally, GM was multiplied by the vertical depth of the net tow at each site to estimate the areal rate of consumption of metazooplankton $\left(\mathrm{GM}_{\mathrm{C}}, \mathrm{mg} \mathrm{C} \mathrm{m}^{-2} \mathrm{~d}^{-1}\right)$.

\subsubsection{Sinking flux}


Sediment traps were used to collect organic particles that settle down along the water column. Two sediment traps (63 cm high, $6 \mathrm{~cm}$ internal diameter) were moored at each site. To avoid re-suspended material bias as possible, the traps were deployed at two or three meters from the bottom depending on the station's depth (Lagoon: 7-8 m; Channel: 6-7 m; Bay: 14-16 m). Prior to their deployment, traps were filled with the dense seawater $(0.2 \mu \mathrm{m}$ filtered seawater $+\mathrm{NaCl}$ at final concentration of $5 \mathrm{~g}^{-1}$ ) to create a density gradient in order to prevent the collection of surface particles. After $24 \mathrm{~h}$ of mooring, the traps were returned to the laboratory and stored at $5^{\circ} \mathrm{C}$ for a night to let the particles settle. For each station, bottom fractions of the two moored traps were mixed together. Subsamples were taken from the trapped material to estimate POC as detailed above (section 2.2). The sinking flux (mg C m $\mathrm{m}^{-2}$ ) of POC was estimated as the carbon stock collected in the trap $(\mathrm{mg} \mathrm{C})$ divided by the area of the trap $\left(6.3 \times 10^{-3} \mathrm{~m}^{-2}\right)$ and the duration of deployment (1 day). Other subsamples from the trapped material were fixed with acid Lugol solution (final concentration of 4\%) for nano- and microphytoplankton cell identification and abundance estimation. Cell abundances were then

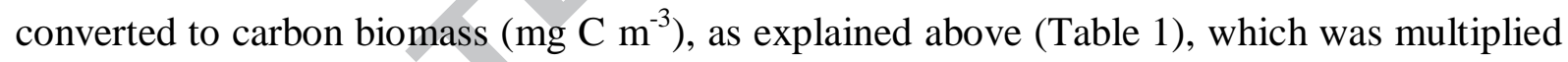
by the volume of trapped materiel and divide by 2 to get the algal carbon stock collected in one trap (mg C). This was then divided by the area of the trap and the duration of deployment to get sinking flux $\left(\mathrm{mg} \mathrm{C} \mathrm{m}^{-2} \mathrm{~d}^{-1}\right)$ for each phytoplankton fraction (i.e. nano- and microphytoplankton).

Additional subsamples (15-30 ml settled volumes) were preserved in buffered formaldehyde for faecal pellet enumeration and volume estimation $\left(\mathrm{mm}^{3} \mathrm{~L}^{-1}\right)$ using an inverted microscope (10 x objectives) following the Utermöhl method (1958). The volume sinking flux $\left(\mathrm{mm}^{3} \mathrm{~m}^{-2}\right.$ $\mathrm{d}^{-1}$ ) were then calculated for each category of pellet (cylindrical/conical; ovoid/rounded) as described by Grami et al. (2008). Then the volume vertical flux was converted to carbon 
vertical flux ( $\mathrm{mg} \mathrm{C} \mathrm{m}^{-2} \mathrm{~d}^{-1}$ ) using a factor of $0.057 \mathrm{mg} \mathrm{C} \mathrm{mm}^{-3}$ for cylindrical/conical pellets and $0.042 \mathrm{mg} \mathrm{C} \mathrm{mm}^{-3}$ for ovoid/ rounded ones (Grami et al., 2008).

\subsection{Model development}

Field data were used to construct pelagic food-web models that quantitatively illustrate carbon pathways in the three study sites. Since the unknown flows outnumbered the known flows, the LIM-MCMC method (Van den Meersche et al., 2009), derived from the inverse analysis method of Vézina and Platt (1988) was adopted to reconstruct trophic carbon flows through the three pelagic food webs. The approach is based on four steps: (1) building an a priori model including all possible flows between the considered compartments or between the compartments and the outside, (2) setting mass-balance between flows, for each compartment, as equalities, (3) setting two groups of inequalities, the first ones based on in situ calculated flows and the second ones consists on a number of biological constraints picked from the literature, to reduce the range of possible values for each unknown flow, and (4) calculating the possible solutions for unknown flows.

\subsubsection{Compartments}

The number of considered compartments and the possible flows/links between them and the outside were considered as the same for the three networks (Channel, Lagoon, and the Bay). Each model contained seven living compartments: heterotrophic bacteria (bac), picophytoplankton $<2 \mu \mathrm{m}$ (pic), nanophytoplankton 2-10 $\mu \mathrm{m}$ (nan), microphytoplankton 20$200 \mu \mathrm{m}$ (mic), protozooplankton $<200 \mu \mathrm{m}$ (including heterotrophic nanoflagellates, dinoflagellates, and ciliates), metazooplankton 200-700 $\mu \mathrm{m}$ (met1), and metazooplankton $>700 \mu \mathrm{m}$ (met2). The non-living compartments were the dissolved organic carbon (doc) and detrital organic carbon (det).

\subsubsection{A priori model}


The gross primary production of the three size fractions of phytoplankton (pic, nan, and mic) are the only sources of particulate organic carbon input to the networks (Fig. 2). Carbon output from the network was driven by respiration of all living compartment and sinking of all compartments except protozooplankton, picophytoplankton, and heterotrophicbacteria.

Detritus dissolution and doc production by all living compartments contribute to doc input. Detritus and doc can be lost from the system by advection. Bacteria, were the only compartment that uses doc, while protozooplankton the only compartment that graze on them. Production of detritus is assigned to phytoplankton (nan and mic) and protozooplankton through their mortality and metazooplankton via their faecal pellets production. The three size fractions of phytoplankton were grazed by protozooplankton, while only nano- and microphytoplankton fractions can be grazed by metazoa. Metazooplankton 200-700 $\mu \mathrm{m}$ (met1) consume protozooplankton and detritus, while metazoa >700 $\mu \mathrm{m}$ (met2) consume protozooplankton, small metazoa (met1) and detritus. The a priori model is presented in Fig. 2.

\subsubsection{The set of equalities (mass balances)}

Setting equations (equalities) is an essential step to impose the mass balances of the network. The mass balance equations for all compartments are given in Table 2. The mass balance equation for each compartment states that the sum of the flows entering any compartment is equal to the sum of the outflows, meaning that we neglected daily variations of biomass compared to daily flow values.

\subsubsection{Biological constraints (inequalities)}

Imposing ecological limits (maximum and/or minimum) for each unknown flow helps to reduce the range of possible solutions. Two ranges of inequalities were adopted. Firstly, estimated flows derived from field experiments were used as mean values for each model. These mean values did not allow the model to estimate flows with certainty. For this reason, 
we proposed to define the minimal and a maximal value for each flow by the calculation of a confidence interval around the field data, i.e. using the minimum and maximum of the average value of each flow (Table 3). The production rates $\left(\mathrm{mg} \mathrm{C} \mathrm{m} \mathrm{d}^{-2}\right)$ of bacteria and phytoplankton size fractions (pic, nan, and mic), as well as their grazing rates $\left(\mathrm{mg} \mathrm{C} \mathrm{m}^{-2} \mathrm{~d}^{-1}\right)$ by protozoa, derived by dilution technique, were integrated as minimum and maximum flows into the model. Microphytoplankton sedimentation flow was constrained by the minimal and maximal estimated values for each site. Metazooplankton gut content experiments allowed constraining (by a minimum and a maximum value) two flows for each model: grazing of nano- and micro-phytoplankton by metazoan 1 and metazoan 2. Metazoa and detritus sedimentation were respectively constrained by a minimum and a maximum value estimated by field experiment for each site. A total of 26 inequalities derived from field experiments realized for the present study were considered for the Lagoon, the Channel, and the Bay of Bizerte.

A second group of constraints was adopted from previous works to constrain the unknown flows (Vézina and Platt, 1988;Steinberg et al., 2000;Vézina and Pahlow, 2003), including: the minimum and maximum respiration rate of phytoplankton, zooplankton, and bacteria; the minimum and maximum doc production rate by phytoplankton and zooplankton (only the upper limit was fixed for bacteria); the lower and upper limit of zooplankton and bacteria growth efficiency; the lower and upper limit of zooplankton assimilation efficiency, detritus excretion, and detritus dissolution flow upper limit. Forty-four inequalities of this second group were applied in the Lagoon, the Channel, and the Bay model (See details in Table 4).

\subsubsection{Solutions}

The last step of the inverse analysis was the calculation of unknown flows. The estimates of each unknown flow were obtained by the LIM-MCMC method, based on the mirror technique defined by Van den Meersche et al. (2009). A jump value of $10 \mathrm{mg} \mathrm{C} \mathrm{m}{ }^{-2} \mathrm{~d}^{-1}$ and 300000 
iterations were adopted to run the models in order to optimize the coverage of all the possible solutions (i.e. correct polytope exploration). A Matlab ${ }^{\odot}$ translation by Alain Vézina and Lauriane Campo of the R-CRAN project package LIM-Solve was used (Weinbauer, 2002; Van den Meersche et al., 2009). More details on the method are available in Van den Meersche et al. (2009) and Niquil et al. (2012).

\subsection{Network analysis}

To characterize the food web obtained by the LIM-MCMC approach, Ecological Network Analysis (ENA) was applied to the obtained flow values. ENA derived indices are commonly used to describe emergent properties of any ecosystem (Ulanowicz, 1986). The algorithms used here were written for Matlab ${ }^{\odot}$ by Carole Lebreton and Markus Schartau. A number of calculated indices were considered in this study for site comparison and characterization:

- Total system throughput (TST): the sum of all the flows circulating through all compartments and a measure of the total system activity (Kay et al., 1989).

$$
\mathrm{TST}=\sum_{\mathrm{i}=1, \mathrm{j}=1}^{\mathrm{n}} \mathrm{T}_{\mathrm{ij}}
$$

where, i:flow out of the system from $i, i=1, \ldots n$; j: flow in to the system to $j, j=1 \ldots n$; and Tij: flow from compartment $i$ to compartment $j$.

- Ascendency (A) and Development Capacity (DC):

Ascendency represents the organized part of the ecosystem. It is the product of the throughput and the Average Mutual Information (AMI: degree of specialization of flows in a network) (Ulanowicz, 2004), and merges the quantification of the system activity and the degree of specialization (Ulanowicz and Wulff, 1991; Ulanowicz, 2000).

$$
A=\sum_{i j}\left(T_{i j}\right) \times \log \left(\frac{T_{i j} \times T S T}{T_{j} \times T_{i}}\right)
$$


where, $\mathrm{T}_{\mathrm{i}}$ : Total outflow from compartment $\mathrm{i} ; \mathrm{T}_{\mathrm{j}}$ : Total inflow for compartment $\mathrm{j}$; and Tij:

Flow from compartment $\mathrm{i}$ to compartment $\mathrm{j}$.

The development capacity (DC) is the sum of A and Overhead (O), which represents the maximum possible value of Ascendency that an ecosystem may reach.

$$
\mathrm{DC}=-\mathrm{TST} \times \sum_{\mathrm{ij}} \frac{\mathrm{T}_{\mathrm{ij}}}{\mathrm{TST}} \times \log \left(\frac{\mathrm{T}_{\mathrm{ij}}}{\mathrm{TST}}\right)
$$

where, $\mathrm{i}$ : flow out of the system from $\mathrm{i}$; $\mathrm{j}$ : flow in to the system to $\mathrm{j}$; and Tij: flow from compartment $\mathrm{i}$ to compartment $\mathrm{j}$.

Ascendency is a more informative metric when it is expressed in relation to development capacity (relative Ascendency, A/DC). It defines the degree of ecosystem development. High A/DC ratios are thought to reflect a high degree of organization, highly specialized and less redundant pathways (Baird et al., 1991; Baird et al., 1998).

$$
\mathrm{AC}=\frac{\mathrm{A}}{\mathrm{DC}}
$$

- Average path length (APL): is the average number of compartments crossed by a unit of carbon from entering to exiting the ecosystem. It represents a measure of the ecosystem retention capacity (Kay et al., 1989).

$$
\mathrm{APL}=\frac{\sum \mathrm{d} \mathrm{i} \leftrightarrow \mathrm{j}}{\frac{\mathrm{N}(\mathrm{N}-1)}{2}}
$$

where, i: flow out of the system from $\mathrm{i} ; \mathrm{j}$ : flow in to the system to $\mathrm{j}$; and $\mathrm{N}$ is the number of vertices in graph.

- Finn Cycling Index (FCI): is the ratio of carbon flowing in loops to the sum of all carbon flows. It quantifies the fraction of all flows involved in recycling (Finn, 1976) and can be considered as a measure of the retentiveness of the system.

$$
\mathrm{FCI}=\frac{\mathrm{TSTc}}{\mathrm{TST}}
$$


where, TSTc is the total flow that is recycled.

\subsection{Cliff's $\delta$ test for comparing network indices between sites}

As suggested by Tecchio et al. (2016), we use the Cliff $\boldsymbol{\delta}$ method for statistically testing the ENA index differences between the models. This method is necessary when we have large sample sizes (here 300000 values for each flow), which precludes us from using other tests like ANOVA or $t$-tests. For each ENA index, three pairwise comparisons were performed. Then, the following values were used to define small, medium, and large effects (i.e. $|\boldsymbol{\delta}|$ <0.147 "negligible"; $|\boldsymbol{\delta}| \quad 0.147-0.33$ "small"; $|\boldsymbol{\delta}| \quad 0.33-0.474$ "medium"; >0.474 "large" according to Tecchio et al. (2016).

\section{Results}

\subsection{Input, output and throughput}

Calculated flows are given in Table 5 and Figure 3. At each site, the food web was only powered by the phytoplankton gross primary production. The phytoplankton production reached $1234 \mathrm{mg} \mathrm{C} \mathrm{m}^{-2} \mathrm{~d}^{-1}$ in the Lagoon and $966 \mathrm{mg} \mathrm{C} \mathrm{m}^{-2} \mathrm{~d}^{-1}$ in the Channel, but only $727 \mathrm{mg} \mathrm{C} \mathrm{m}^{-2} \mathrm{~d}^{-1}$ in the Bay. For the three networks, microphytoplankton (mic) exhibited the highest contribution to total carbon input (70-83\%). Picophytoplankton contribution fluctuated between $8-16 \%$, while nanophytoplankton production varied between $8 \%$ and $13 \%$ of total carbon input.

Carbon exited the food webs (outputs) either through respiration (res) or dissolved organic carbon (doc) loss or downward sedimentation flows of detritus (det), phytoplankton (nan and mic), and zooplankton (met1 and met2). Carbon loss by respiration reached $14-16 \%$ of total carbon circulating for the three sites. It represents the main factor of carbon output at the site level, i.e. in the Lagoon (39\%), the Channel (46\%), and the Bay (45\%). The highest respiration flows within a compartment were those from the protozooplankton and metazooplankton (19-20\% and 13-19\% of total carbon outputs, respectively, Fig. 4A). 
Carbon sinking contributed $31 \%$ of total carbon loss in the Lagoon, $29 \%$ in the Channel, and $25 \%$ in the Bay. Microphytoplankton and metazooplankton $>700 \mu \mathrm{m}$ (met2) were the main living compartment contributing to sinking flows (Fig. 4B).

Throughput was defined as the sum of carbon flows incoming or leaving a compartment. Microphytoplankton followed by protozooplankton and metazooplankton showed the highest values of carbon throughput (609-868 $\left.\mathrm{mg} \mathrm{C} \mathrm{m}^{-2} \mathrm{~d}^{-1}\right)$ among the living compartments of the three networks (Fig. 5). Detritus also presented relatively high throughput of carbon (230$\left.531 \mathrm{mg} \mathrm{C} \mathrm{m}^{-2} \mathrm{~d}^{-1}\right)$.

\subsection{Production of dissolved organic carbon and detritus}

The doc production at each site amounted to 334,274 , and $208 \mathrm{mg} \mathrm{C} \mathrm{m}^{-2} \mathrm{~d}^{-1}$ in the Lagoon, the Channel, and the Bay, respectively (Fig. 6A). The metazooplankton (met1 and met2) were the main compartment that contributed (36-40\%) to doc in the Lagoon $\left(130 \mathrm{mg} \mathrm{C} \mathrm{m}^{-2} \mathrm{~d}^{-1}\right)$ and the Bay (76 $\mathrm{mg} \mathrm{C} \mathrm{m}^{-2} \mathrm{~d}^{-1}$ ) (Table 5, Fig. 6A). In the Lagoon, the phytoplankton exudation (115 $\mathrm{mg} \mathrm{C} \mathrm{m}^{-2} \mathrm{~d}^{-1}$, i.e. $34 \%$ of doc production) was higher than the protozooplankton excretion (89 $\mathrm{mg} \mathrm{C} \mathrm{m}^{-2} \mathrm{~d}^{-1}$, i.e. $26 \%$ of doc production), whereas both flows were similar in the Bay (65.9 and $66.4 \mathrm{mg} \mathrm{C} \mathrm{m}^{-2} \mathrm{~d}^{-1}$ ). For the Channel, the three algal compartments (mic, nan, and picophytoplankton) contributed almost equally $(32,34$, and $35 \%)$ to doc $(84,94$, and $\left.96 \mathrm{mg} \mathrm{C} \mathrm{m} \mathrm{d}^{-1}\right)$. It is important to highlight here that the microphytoplankton contributed $66-81 \%$ to total algal exudation.

Detritus production by all living compartments was high in the Lagoon (531 $\mathrm{mg} \mathrm{C} \mathrm{m}^{-2} \mathrm{~d}^{-1}$ ) compared to the Channel (229 $\mathrm{mg} \mathrm{C} \mathrm{m}^{-2} \mathrm{~d}^{-1}$ ) and the Bay (285 $\mathrm{mg} \mathrm{C} \mathrm{m}^{-2} \mathrm{~d}^{-1}$ ) (Fig. 6B). Half of the detritus production derived from microphytoplankton in the Lagoon and the Bay. In these sites, protozooplankton (16 and 22\%) and metazooplankton (i.e.; met 1 and met2, 23 and $25 \%$ respectively) presented almost similar contributions to detritus production. In the Channel, most of the detritus production resulted from protozooplankton (41\%) and 
metazooplankton (40\%) activities whereas phytoplankton had a lower contribution (19\%) (Fig. 6B).

\subsection{Zooplankton diets}

The protozooplankton diet was mainly based on herbivory, as microalgae constituted the main prey for these protozoa in the three sites $(60-77 \%$ of the protozooplankton diet, Fig. 7A). Nanophytoplankton formed only $3-13 \%$ of total carbon consumed by protozooplankton in all sites, while picophytoplankton contributed more to the consumption of protozooplankton (11$23 \%$ ). Protozooplankton showed very weak bacterivory, since bacteria formed only $10 \%$ of their diet in the Channel and not more than $5 \%$ in the Lagoon and the Bay.

In the Lagoon and the Bay, the metazooplankton 200-700 $\mu \mathrm{m}$ (met1) were mainly detritivorous, since detritus represented $52-58 \%$ of their diet (Fig. 7B). At both sites, protozooplankton contributed $32-39 \%$ of the met1 consumption while phytoplankton guaranteed only 5\%. In the Channel, the smaller metazooplankton was carnivorous, with a diet that relied mainly on protozooplankton (54\%) (Fig. 7B). Detritus and phytoplankton formed 31 and $10 \%$ of met1 diet, respectively, in this site.

At the three stations, the metazooplankton $>700 \mu \mathrm{m}$ (met2) was mainly carnivorous, since $48-62 \%$ of their diet were composed of protozoa and metazoa 200-700 $\mu \mathrm{m}$ (Fig. 7C). The remaining source of carbon came principally from detritus in the Lagoon (42\%) and the Bay (38\%), where herbivory did not represent more than $10 \%$. In the Channel, phytoplankton and detritus contributed almost equally ( 21 and $26 \%$, respectively) to the carbon demand of met2 (Fig. 7C).

\subsection{Ecosystem indicators and Ecological Network Analysis indices.}

Flow estimates obtained from the LIM-MCMC were used to calculate ecological networks indices (Fig. 8). This showed that the total system throughput (TST) was higher in the Lagoon (4798 $\mathrm{mg} \mathrm{C} \mathrm{m}^{-2} \mathrm{~d}^{-1}$ ) compared to the Channel (3818 $\mathrm{mg} \mathrm{C} \mathrm{m}^{-2} \mathrm{~d}^{-1}$ ) and the Bay (2934 mg C 
$\mathrm{m}^{-2} \mathrm{~d}^{-1}$ ), due to higher primary production by phytoplankton. Also the development capacity (DC) in the Lagoon (14195 $\mathrm{mg} \mathrm{C} \mathrm{m}^{-2} \mathrm{~d}^{-1}$ ) significantly exceeded those of the Channel (11106 $\mathrm{mg} \mathrm{C} \mathrm{m} \mathrm{d}^{-1}$ ) and the Bay (8489 $\mathrm{mg} \mathrm{C} \mathrm{m}^{-2} \mathrm{~d}^{-1}$ ) (Table 6, Fig. 8). Ascendency showed a similar pattern as DC, with higher values for the Lagoon (7686 $\left.\mathrm{mg} \mathrm{C} \mathrm{m}^{-2} \mathrm{~d}^{-1}\right)$ and the Channel (6054 $\mathrm{mg} \mathrm{C} \mathrm{m}^{-2} \mathrm{~d}^{-1}$ ) compared to the Bay (4839 $\mathrm{mg} \mathrm{C} \mathrm{m}^{-2} \mathrm{~d}^{-1}$ ). Conversely, a high relative ascendency was founded in the Bay $(\mathrm{A} / \mathrm{DC}=57 \%$, Fig. 8) in comparison to the Lagoon and the Channel $(\mathrm{A} / \mathrm{DC}=55 \%)$.

The average path length (APL) differed significantly between the Lagoon (2.95) and the Channel (2.88) (Table 6). While the Bay had the highest APL value (3.03), suggesting that a unit of carbon crossed more compartments during its path through the trophic system (from input e.g. gross primary production, to output: e.g. respiration) compared to the Lagoon and the Channel. The Finn cycling index (FCI) showed slightly higher and significant cycling activity in the Channel (14\%) compared to the Bay (13\%) or the Lagoon (12\%) (Table 6, Fig. 8).

\section{Discussion}

\subsection{Plankton food webs of the study sites}

Mediterranean coastal waters are currently under several anthropogenic pressures, including eutrophication and pollution, but few studies have addressed the impact of these stressors on their functioning and food web structure. Here, we have presented new results concerning the food web and its associated properties in three coastal waters habitats in the SW Mediterranean Sea. Although these sites are closely located, they are different in eutrophic status, contamination levels, hydrology, and geomorphology (Bejaoui et al., 2008; Boufahja et al., 2012; Louati et al., 2013; Barhoumi et al., 2014a, b). These factors may impact plankton diversity and dynamics as well as productivity (Smayda and Reynold, 2001; Sakka Hlaili et 
al., 2006; Leboulanger et al., 2011; Lafabrie et al., 2013). Therefore, variability in the structure and functioning of the plankton food web among sites may be suspected. Indeed, the LIM-MCMC approach revealed that the three ecosystems differed in their productivity which could be reflected in their planktonic system functions.

The photosynthetic carbon input was sufficient to support the functioning of the three food-web models. As expected, the inshore waters with substantial nutrients loading (Sakka Hlaili et al., 2008; Ben Garali et al., 2010; Sahraoui et al., 2012) exhibited high production rate (1234-966 $\mathrm{mg} \mathrm{C} \mathrm{m}^{-2} \mathrm{~d}^{-1}$ ). Similar production rates were previously found for the Lagoon of Bizerte (1872 mg C m $\mathrm{m} \mathrm{d}^{-1}$, Grami et al., 2008) and the Bay of Biscay (French Atlantic Gulf; 1145-1666 mg C m $\mathrm{m}^{-1}$, Marquis et al., 2007). These values are however low compared to other values recorded in temperate ecosystems, like the shelf of the Gulf of Cadiz (Spanish South Atlantic Gulf; $4500 \mathrm{mg} \mathrm{C} \mathrm{m}^{-2} \mathrm{~d}^{-1}$; Huertas et al., 2005). The production rate in the Bay (727 $\mathrm{mg} \mathrm{C} \mathrm{m}^{-2} \mathrm{~d}^{-1}$ ) was similar to those of Arcachon Bay (French Atlantic Coast; $433 \mathrm{mg} \mathrm{C} \mathrm{m} \mathrm{d}^{-1}$, Tortajada et al., 2012) and the Bay of Biscay during late spring (French Atlantic Gulf; $631 \mathrm{mg} \mathrm{C} \mathrm{m} \mathrm{d}^{-1}$, Marquis et al., 2007). For all study sites, phytoplankton production (727-1234 $\mathrm{mg} \mathrm{C} \mathrm{m}^{-2} \mathrm{~d}^{-1}$ ) was higher than the bacterial production

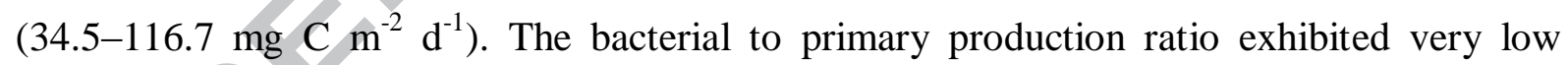
values in the Lagoon (0.03) and the Bay (0.06), which was close to those found in other coastal systems such as the Bay of Biscay (0.03-0.04, Marquis et al., 2007), the northern Spanish coast (0.04; Teira et al., 2003), and the Arcachon Bay (0.02, Tortajada et al., 2012). In the Channel, this ratio amounted to 0.12 but it was still lower than the value reported at a global scale (0.3; Cole et al., 1988).

In these three locations, the primary production was mainly sustained by microphytoplankton (70-80\%). Diatoms and autotrophic dinoflagellates were the main microphytoplankton taxa at all stations and dominated the algal biomasses (Sakka Hlaili et al., 2007; Meddeb et al., 
submitted). Since microphytoplankton known to be selected by herbivorous zooplankton, the dominance of the herbivorous pathway from the typology of Legendre and Rassoulzadegan (1995, 1996; redefined in Sakka Hlaili et al. 2014) is suspected at the three sites. Nevertheless, a previous study has reported the dominance of the microbial food web in the Bizerte Lagoon during summer, although diatoms were prevailing during this season (Grami et al., 2008). Similarly, the microbial food web was shown to act in other coastal regions, where diatoms were abundant (Umani and Beran, 2003; Berglund et al., 2005).

At each site, carbon left the pelagic ecosystem firstly by respiration, then by sinking vertically and finally through doc losses, each loss represented by $39-46 \%, 25-31 \%$ and $24-30 \%$ of total outputs, respectively. Respiration was mainly driven by metazooplankton and protozooplankton activities (19-20\% and 13-19\% of total carbon outputs, respectively). Phytoplankton respiration had a low contribution (5-6\%) to total carbon losses. This was comparable to a previous study in the Bizerte Lagoon ( $\sim 5 \%$, Grami et al., 2008), but much less so than in the Bay of Biscay (57-82\%; Marquis et al., 2007) and at Lake Pavin (26\%, Grami et al., 2011). Bacterial respiration was very weak, contributing only to $1-3 \%$ of carbon output, which may be related to low bacterial production rates. The two size classes of metazooplankton (met1 and met2) exhibited the highest vertical sinking flux that represented $14-19 \%$ of total carbon output. These trophic components produced important fraction (23$40 \%)$ of total detritus.

In the Channel, the sinking of phytoplankton (particularly of microphytoplankton) represented $12 \%$ of total carbon losses. However, it did not exceed $7 \%$ in the Lagoon and the Bay despite $50 \%$ of total detritus production made up by microphytoplankton at these sites. This change may be caused by the high detritivory activity of metazooplankton at these two sites (Fig. 6). In addition, detritus sinking accounted for only 3.5-5.5\% of total carbon output, which highlighted the important occurrence of detritivorous metazooplankton. 
When considering the carbon throughput (i.e. activity of each compartment) in the three sites, the most active compartments were microphytoplankton, followed by protozooplankton and metazoopankton, suggesting their important role, as producers and grazers. In contrast, the bacteria exhibited the lowest Throughput value (Fig. 5) which was consistent of their low production and respiration. The bacterial uptake of doc was also low (Table 5) corresponding to $8-30 \%$ of doc, which resulted from plankton exudation/excretion and from detritus dissolution. In parallel to the low activity of bacteria, a low fraction of bacterial production was grazed by protozooplankton at the three sites (29-49\% of their total grazing). These values were in the same range of those reported in previous study for Bizerte Lagoon during summer (25-50\%, Grami et al., 2008), Arcachon Bay (50\%, Tortajada et al., 2012) and the Lake Pavin (48\%, Grami et al., 2011). During our study, small protozooplankton, including aloricate ciliates (Strombidium spp.) and heterotrophic nanoflagellaes (Leucocryptos spp.), represented less than $5 \%$ of total protozooplankton carbon biomass (Meddeb et al. (submitted). Since protozooplankton have a weak bacterivory, they would satisfy their carbon demand by consuming large fraction $(>80 \%)$ of picphytoplankton production. During the sampling season (i.e. spring), the protozooplankton were mostly composed by $>50 \mu \mathrm{m}$ heterotrophic dinoflagellates (i.e. Protoperidinium spp.) and tintinnid ciliates (i.e. Paravavella gigantea and Tintinnopsis corniger) (70-95\% of total biomass, Meddeb et al., submitted). This means that their herbivory was suspected to be high. At the same time, these large protozooplankton could be potential prey for the metazooplankton and hence can contribute to channel carbon in each site. To elucidate the real role of each grazer's group in the studied pelagic ecosystems, the composition of each diet of the proto- and metazooplankton were analysed. This may also permit a characterization of the dominant pathways of biogenic carbon. 
As suspected in our hypothesis, during spring the diet of protozooplankton relied mainly on phytoplankton (90-98\%), with large contribution of microphytoplankton (60-77\%). The remaining carbon demand of protozooplankton was supported by bacteria (5-10\%). A similar result was previously reported in the Bizerte Lagoon during the summer season (with $62 \%$ of autotrophs and $17 \%$ of bacteria; Grami et al., 2008), in the spring season at Arcachon Bay (with $84 \%$ of autotrophs and $16 \%$ of bacteria; Tortajada et al., 2012), and again in spring at the Bay of Biscay (with $88 \%$ of autotrophs and $12 \%$ of bacteria; Marquis et al., 2007). In contrast, in other regions, such as Lake Biwa, the main carbon input to protozooplankton was detritus (45\%) and bacteria (52\%) (Niquil et al., 2006). In the Bay of Biscay during spring, the major food source was picophytoplankton, which contributed $64-83 \%$ of total carbon input; while in the late spring the protozooplankton diet was composed of bacteria and phytoplankton in roughly equal shares (Marquis et al., 2007).

Small metazooplankton $(200-700 \mu \mathrm{m})$ seemed to be mainly detritivorous in the Lagoon and the Bay of Bizerte during spring (detritus formed $52-58 \%$ of their diets), whereas in the Channel, protozooplankton constituted important fraction of their ingested carbon (54\%). Larger mesozooplankton $(>700 \mu \mathrm{m})$ were mostly carnivorous, as protozooplankton and small metazooplankton $(200-700 \mu \mathrm{m})$ formed half of their diets at all sites, but detritus represented a non-negligible carbon source for the met $2(21-42 \%)$. In all sites, diets for both size classes of metazooplankton relied less on phytoplankton (10,21, and 5\% for Lagoon, Channel and Bay, respectively). When considering all zooplankton, the detritivory:herbivory (D:H) ratio varied from 0.25 to 0.77 for the three sites during spring. These values were very similar to those already reported for the Bizerte Lagoon in spring (0.23-0.74, Grami et al., 2008). Then, detritus do not have a principal role in channelling carbon through the three planktonic food webs. The planktonic food webs rely mostly on the herbivory of zooplankton. To stress the importance of protozooplankton compared to metazooplankton as autotrophic carbon 
consumer, two specific ratios were adapted from Sakka Hlaili et al. (2014): (1) the ratio of the consumption rate of phytoplankton by protozooplankton to the total consumption rate by protozooplankton (R1 ratio) and (2) the ratio of consumption rate of phytoplankton by protozooplankton to the consumption rate of phytoplankton by proto- and metazooplankton ( $\mathrm{R} 8$ ratio). In our case, the $\mathrm{R} 1$ ratio varied from 0.83 to 0.94 , indicating that protozooplankton grazed on more phytoplankton than other prey. In parallel, primary producers were consumed more-so by protozooplankton than metazooplankton, since our R8 ratio varied from 0.82 to 0.99. According to both ratios, the protozooplankton mainly assured the herbivory in the three pelagic ecosystems. Moreover, the protozooplankton removed $40-54 \%$ of nano- and microphytoplankton production per day compared to the $3-14 \%$ grazed by metazooplankton. These mesozooplankton seemed to have a small role in herbivory, but instead they can impose important predatory pressure on protozooplankton and then participate in channelling biogenic carbon.

To identify the dominant trophic pathway in the three planktonic ecosystems, a specific ratio was proposed by Sakka Hlaili et al. (2014): the ratio of picophytoplankton net production to total phytoplankton net production ( $\mathrm{R} 7$ ratio). This ratio was proposed by the authors to discriminate between herbivorous ( $\mathrm{R} 7 \leq 0.1)$, multivorous (R7: $0.1-0.6)$, and microbial food webs $(\mathrm{R} 7 \geq 0.6)$. In the Lagoon and the Channel, the ratio values ( 0.13 and 0.11 , respectively) are very close to the lower limit of R7 (0.1) that discriminates the multivorous structure of the herbivorous one. Therefore, food webs in both sites during spring can be considered to be approximately multivorous but tend towards the herbivorous pathway. In the Bay of Bizerte, the herbivorous pathway was more dominant, at 0.08 .

\subsection{Structural and functional proprieties of identified food webs}

The ENA indices have proved to be very useful to characterize ecosystem functioning, to describe the activity and the retention capacity as well as the level of organization and 
maturity of the food webs, and to detect any change in their environments (Proulx et al., 2005; Heymans et al., 2007). These indicators have been frequently used, especially to assess the impact of natural and anthropogenic pressures on coastal marine ecosystems (Belgrano et al., 2005; Niquil et al., 2014; Piroddi et al., 2015; Chaalali et al., 2016). They also provide useful information on the degree of stress and stability of food webs (Grami et al., 2008; Heymans et al., 2014; Saint-Béat et al., 2015). Besides, ENA indices were potentially very valuable in inter-ecosystem comparisons.

Considering the total system throughput (TST), the highest values were observed for the Lagoon (4798 $\mathrm{mg} \mathrm{C} \mathrm{m}^{-2} \mathrm{~d}^{-1}$ ) and the Channel (3818 $\mathrm{mg} \mathrm{C} \mathrm{m}^{-2} \mathrm{~d}^{-1}$ ) (large and medium difference) compared to the Bay (2934 $\mathrm{mg} \mathrm{C} \mathrm{m}^{-2} \mathrm{~d}^{-1}$ ) (Table 6; Fig. 8). This means that the Lagoon and the Channel were most active as they had high productivity, which can be related to their high degree of eutrophication. These semi-enclosed ecosystems are closer to sources of nutrient discharges compared to the Bay that has larger exchange with the Mediterranean Sea (Fig. 1). Previously, Grami et al. (2008) have also shown high TST within the Lagoon of Bizerte, which was directly related to the proximity of the study station to sources of nutrient discharge (urban and shellfish farming input). Our results are in line with the estimates obtained for other eutrophic ecosystems. For example, some South African ecosystems are very active with high TST values (Niquil et al., 2012) reflecting high production, which rely on the strong activity of the benthic compartments (macrophytes as main primary producers in salt marshes) (Scharler et al., 2005).

The relative ascendancy (A/DC) represents the total activity that has been converted into organized complexity. It equalled 57\% in the Bay and 55\% in the Lagoon and the Channel of Bizerte (Fig. 8), suggesting that the Bay is more organized that the two other ecosystems. Some ecosystems, such as Kromme Estuary (South Africa), exhibited low A/DC (35\%, Scharler et al., 2005) because of severe limitations in freshwater inflow that caused a decline 
of the internal organization and maturity (Baird and Heymans, 1996). On the Italian coast, higher relative ascendency values appeared to be related to the impact of human and industrial activities focused in the southern part of the Apulian peninsula (Vassallo et al., 2006).

According to Monaco and Ulanowicz (1997), recycling is considered to be an important indicator of an ecosystem's ability to maintain its structure and integrity through positive feedbacks, and has been used as an indicator of stress (Ulanowicz, 1986) and ecosystems maturity (Odum, 1969; Christensen, 1995; Vasconcellos et al., 1997). Cycling reduces the impact of a perturbation on an ecosystem by acting as a buffer and it seems to increase the resistance of the system (Saint-Béat et al., 2015). Therefore, the Finn's cycling index (FCI, Finn, 1976) has been shown to be correlated with ecosystem maturity, resilience, and stability and high FCI is a feature of mature ecosystem (Christensen et al., 2005; Duan et al., 2009, Niquil et al., 2012). In our study, the FCI was generally quite low (12-14\%), suggesting that the study sites are disturbed ecosystems and that they are not mature. This may be due to anthropogenic stresses, such as eutrophication and chemical contamination. Patrício et al. (2004) has shown that FCI decreased from $20.24 \%$ to $19.46 \%$ between moderate and strongly eutrophic waters. Similarly, Duan et al. (2009) have reported a drastic decrease of the FCI for the Pearl River Estuary between 1981 (9.21\%) and 1998 (2.72\%) due to a continuing pollution since 1980. Piroddi et al. (2015) showed that the Amvrakikos Gulf (Western Greece) was an immature and perturbed ecosystem (FCI $=16 \%)$, typical of "closed" ecosystems (e.g., like estuaries, lagoons, and bays) where bottom-up prevail over top-down processes, and where possibly high levels of community stress are induced by anthropogenic and environmental forces. In a previous study, conducted in the Bizerte Lagoon in 2004 (Grami et al., 2008), the FCI was found to be higher (21\%) than our estimate (12\%). During last decade, the Lagoon has undergone increasing anthropogenic pressure, as several new industrial factories are located on its shores and the number of shellfish farms has tripled. This 
has obviously contributed to an increase of eutrophic and polluted status of the Lagoon, which was confirmed by a decrease of the FCI from 2004 to 2012. Unfortunately, no previous data existed for the Channel and the Bay, so our study is a first report modelling the perturbed status of these waters.

To compare the degree of perturbation among the study sites, the average path length (APL) was used. This descriptor is expected to be longer in systems with high degree of flow diversity and cycling (Christensen, 1995; Thomas and Christian, 2001). Increasing the number of links increases the robustness of interactions of an ecosystem (Lafferty et al., 2008), and its overall organization (Lafferty et al., 2006). The APL reached higher value in the Bay (3.03 components per average food cycle) than the two other sites $(2.88-2.95)$.So, compared to the Bay, the Lagoon and the Channel were more stressed. As mentioned, both sites have undergone higher chemical pollution and nutrient loading than the Bay (Bejaoui et al., 2010; Sahraoui et al., 2012; Barhoumi et al., 2014a, b; Pringault et al., 2016)

\section{Conclusion}

Modelling can be used to investigate, analyse, and compare the functioning of ecosystems subjected to various anthropogenic stresses at different periods. This integrated approach provides many indications on ecosystem health and stability. Several modelling technique exists and are already used for management objectives (e.g: Ecopath, Osmose, Atlantis). More specifically, the LIM-MCMC approach has important complementary features, since it takes into account microbial processes and which can provide confidence intervals for statistical comparisons. Our study has highlighted the status and the functioning of three interconnected sites during the spring of 2012 (Lagoon, Channel, and Bay of Bizerte), subjected to various anthropogenic pressures. The main results showed that (i) carbon input came from autotrophic primary production, by microphytoplankton, (ii) herbivorous and almost multivorous food-webs were the dominant carbon pathways in the study sites during spring, and (iii) the 
herbivorous activity was mainly driven by the protozooplankton, which played a major role in the transfer of biogenic carbon to higher trophic levels.

The different indices used in our study showed that the Lagoon and the Channel seemed to be more stressed, more active, and less organized compared to the Bay of Bizerte. This directly reflects the difference in the degrees of anthropogenic pressure (as eutrophication and chemical pollution) among these ecosystems. Finally, this study supports that inverse modelling combined with ecologicalnetworkanalysis may offer an effective tool for management and assessment of ecosystems health, and to diagnose the occurrence of anthropogenic pressures.

\section{Acknowledgements}

This work was supported by IRD through the JEAI-ECOBIZ and the LIM COSYS-Med. MM was financed by an IRD fellowship (ARTS program). The work of Nathalie Niquil on ENA derived indicators for characterizing the stress in food webs is supported by DEVOTES (DEVelopment Of innovative Tools for understanding marine biodiversity and assessing Good Environmental Status) funded by the European Union under the 7th Framework Programme, 'The Ocean for Tomorrow' Theme (grant agreement no. 308392), www.devotesproject.eu. The English grammar and syntax of the manuscript have been revised by Proof-Reading-service.com. Anonymous referees are warmly acknowledged for triggering substantial enhancements on the early version of this manuscript.

\section{References}

Alekseenko, E., Raybaud, V., Espinasse, B., Carlotti, F., Queguiner, B., Thouvenin, B., Garreau, P., Baklouti, M., 2014. Seasonal dynamics and stoichiometry of the planktonic community in the NW Mediterranean Sea: a 3D modeling approach. Ocean Dynamics64, 179-207.

Auger, P.A., Diaz, F., Ulses, C., Estornel, C., Neveux, J., Joux, F., Pujo-Pay, M., Naudin, J.J., 2011. Functioning of the planktonic ecosystem on the Gulf of Lions shelf (NW Mediterranean) during spring and its impact on the carbon deposition: a field data and 3-D modeling combined approach. Biogeosciences 8, 3231-3261. 
Azam, F., Fenchel, T., Field, J.G., Gray, J.S., Meyer-Reil, L.A., Thingstad, F., 1983. The ecological role of water-column microbes in the sea. Marine Ecology Progress Series 10, 257-263.

Baird, D., Mc Glade, J.M., Ulanowicz, R.E., 1991. The comparative ecology f six marine ecosytems. Philosophical Transactions of the Royal Society of London, Series B. Biological Sciences 333, 15-29.

Baird, D., Heymans, J.J., 1996. Assessment of ecosystem changes in response to freshwater inflow of the Kromme River estuary, St Francis Bay, South Africa: a network analysis approach. Water SA 22, 307-318.

Baird, D., Luczkovich, J., Christian, R.R., 1998. Assessment of spatial and temporal variability in system attributes of the St Marks National Wildlife Refuge, Apalachee Bay, Florida. Estuarine Coastal and Shelf Science 47, 329-34.

Baird, D., 2012. Assessment of observed and perceived changes in ecosystems over time with special reference to the Sylt-Rømø Bight, German Wadden Sea. Estuarine Coastal and Shelf Science 108, 144-154.

Barhoumi, B., LeMenach, K., Dévier, M-H., Ameur, W.B., Etcheber, H., Budzinski, H.,Cachot, J., Driss, M.R., 2013. Polycyclic aromatic hydrocarbons (PAHs) in surfacesediments from the Bizerte lagoon, Tunisia: levels, sources and toxicological significance. Environmental Monitoringand Assessment 186, 2653-2669.

Barhoumi, B., Le Menach, K., Dévier, M.H., El megdiche, Y., Hammami, B., Ameur, W.B., Hassine, S.B., Cachot, J., Budzinski, H., Driss, M.R., 2014a. Distribution and ecological risk of polychlorinated biphenyls (PCBs) and organochlorine pesticides (OCPs) in surface sediments from the Bizerte lagoon Tunisia. Environmental Science Pollution Research21, 6290-6302.

Barhoumi, B., Le Menach, K., Devier, M.H., Ben Ameur, W., Etcheber, H., Budzinski, H., Cachot, J., Driss, M.R., 2014b. Polycyclic aromatic hydrocarbons (PAHs) in surface sediments from the Bizerte Lagoon, Tunisia: levels, sources, and toxicological significance. Environmental Monitoring and Assessment 186, 2653-2669.

Bejaoui, B., Harzallah, A., 2005. Modèle hydrodynamique de la lagune de Bizerte avec forçage saisonnier. Atelier de Modélisation des Écosystèmes Marins, organisé par l'INSTM, Tunis, 27-28.

Bejaoui, B., Harzallah, A., Moussa, M., Chapelle, A., Solidoro, C., 2008. Analysis of hydrobiological pattern in the Bizerte lagoon (Tunisia). Estuarine Coastal and Shelf Science80, 121-129.

Bejaoui B., Ferjani D., Zaaboub N., Chapelle A., Moussa M., 2010.Caractérisation hydrobiologique saisonnière de la lagune de Bizerte. Revue des Sciences De l'eau 23, 215232. 
Belgrano, A., Scharler, U.M., Dunne, J., Ulanowicz, R.E., 2005. Aquatic Food Webs. Oxford U 25-40.

Ben Ameur, W., Trabelsi, S., El Megdiche, Y., Ben Hassine, S., Barhoumi, B., Hammami, B., Eljarrat, E., Barceló, D., Driss, M. R., 2013. Concentration of polychlorinated biphenyls andorganochlorine pesticides in mullet (Mugilcephalus) and sea bass (Dicentrarchuslabrax) from Bizerte Lagoon (Northern Tunisia). Chemosphere 90, 2372-2380.

Ben Garali, M., Ouakad., Gueddari, M., 2010. Contamination of Superficial Sediments byHeavy Metals and Iron in the Bizerte Lagoon, Northern Tunisia. Arabian Journal of Geosciences 3, 295-306.

Ben Mna, H., Oueslati, W., Helali, M.A., Zaaboub, N.,Added., A., Aley, L., 2017. Distribution and assessment of heavy metal toxicityin sediment cores from Bizerte Lagoon, Tunisia. Environmental Monitoringand Assessment, 189-356.

Berggreen, U., Hansen, B. Kigkhoe, A.T., 1988. Food size spectra, ingestion and growth of the copepod Acartiu tonsu during development: Implications for determination of copepod production. Marine Biology 99, 341-352.

Berglund, J., Samuelsson, K., Kull, T., Muren, U., Andersson, A., 2005. Relative strength of resource and predation limitation of heterotrophic nanoflagellates in a low-productive sea area. Journal of Plankton Research 27, 923-935.

Bianchi, C.N., Morri, C., 2000. Marine Biodiversity of the Mediterranean Sea: Situation, Problems and Prospects for Future Research. Marine Pollution Bulletin 40, 367-376.

Boudouresque, C.F., Verlaque, M., 2002. Biological pollution in the Mediterranean Sea: invasive versus introduced macrophytes. Marine Pollution Bulletin 44, 32-38.

Boufahja F., 2010. Approches communautaires et populationnelles de biosurveillance dumilieu marin chez les nématodes libres (lagune et baie de Bizerte, Tunisie). Thèse de doctorat. Faculé des Sciences de Bizerte, Université 7 Novembre Carthage, 422 p.

Boufahja, F., Hedfi, A., Essid, N., Aïssa, P., Mahmoudi, E., Beyrem, H., 2012. An observational study on changes in biometry and generation time of Odontophora villoti (Nematoda, Axonolaimidae) related to petroleum pollution in Bizerte bay, Tunisia. Environmental Science and Pollution Research 19,646-55.

Chaalali, A., Saint-Béat, B., Lassalle, G., Le Loc'h, F., Tecchio, S., Safi, G., Savenkoff, C., Lobry, J., Niquil, N., 2015. A new modeling approach to define marine ecosystems food-web status with uncertainty assessment. Progress in Oceanography 135, 37-47.

Chaalali, A., Beaugrand, G., Raybaud,V., Lassalle, G., Saint-Béat, B., Le Loc'h, F., Bopp, L., Tecchio, S., Safi, G., Chifflet, M., Lobry, J., Niquil, N., 2016. From species distributions to ecosystem structure and function: A methodological perspective. Ecological Modelling 334, 78-90. 
Christensen, V., Pauly, D., 1995. Fish production, catches and the carrying capacity of the world oceans. Naga 18, 34-40.

Cole, J.J., Findlay, S., Pace, M.L., 1988. Bacterial production in fresh and saltwater ecosystems: a cross-system overview. Marine Ecology Progress Series 43, 1-10.

Donali, E., Olli, K., Heiskanen, A.S., Andersen, T., 1999. Carbon flow patterns in the planktonic food web of the Gulf of Riga, the Baltic Sea: a reconstruction by the inverse method. Journal of Marine Systems 23, 251-268.

Duan, L.J., Li, S.Y., Liu, Y., Moreau, J., Christensen, V., 2009. Modeling changes in the coastal ecosystem of the Pearl River Estuary from 1981 to 1998. Ecological Modelling 220, 2802-2818.

Eldridge, P.M., Jackson, G.A., 1993. Benthic trophic dynamics in California coastal basin and continental slope communities inferred using inverse analysis. Marine Ecology Progress Series 99, 115.

Fath, B.D., Scharler, U.M., Ulanowicz, R.E., Hannon, B., 2007. Ecological network analysis: network construction. Ecological Modelling 208, 49-55.

Finn, J.T., 1976. Measures of ecosystem structure and function derived from analysis of flows. Journal of Theoretical Biology 56, 363-380.

Grami, B., Niquil, N., Sakka Hlaili, A., Gosselin, M., Hamel, D., 2008. The plankton food web of the Bizerte Lagoon (South-Western Mediterranean): II. Carbon steady state modeling using inverse analysis. Estuarine Coastal and Shelf Science 79,101-113.

Grami, B., Rasconi, S., Niquil, N., Jobard, M., Saint Béat, B., 2011. Functional Effects of Parasites on Food Web Properties during the Spring Diatom Bloom in Lake Pavin: A Linear Inverse Modeling Analysis. Plos One 6, 23273.

Grattepanche, J.D., Vincent, D., Breton, E., Christaki, U., 2011. Microzooplankton herbivory during the diatom Phaeocystis spring succession in the eastern English Channel. Journal of Experimental Marine Biology and Ecology 404, 87-97.

Harzallah, A., Brahim, M., Sammari, C., Koutitonsky, V., 2003. Water salinity and heat budgets in the lagoon of Bizerte estimated from observations and model simulation. Proceedings of 3rd JICA.

Heymans, J.J., Guénette, S., Christensen, V., 2007. Evaluating network analysis indicators of ecosystem status in the Gulf of Alaska. Ecosystems 10, 488-502.

Heymans, J.J., Coll, M., Libralato, S., Morissette, L., Christensen, V., 2014. Global patterns in ecological indicators of marine food webs: a modelling approach. Plos One 9, 95845.

Hillebrand, H., Dürselen, C.D., Kirschtel, D., Pollingher, U., Zohary, T., 1999. Biovolume calculation for pelagic and benthic microalgae. Journal of Phycology 35, 403-424. 
Hobbie, J.E., Daley, R.J., Jasper, S., 1977. Use of Nucleopore filters for counting bacteria by fluorescence microscopy. Applied and Environmental Microbiology 33, 1225-1228.

Huertas, I. E., Navarro, G., Rodríguez Gálvez, S., 2005. The influence of phytoplankton biomass on the spatial distribution of carbon dioxide in surface sea water of a coastal area of the Gulf of Cádiz (southwestern Spain). Canadian Journal of Botany 83, 929-940.

Jackson, G.A., Eldridge, P.M., 1992. Food web analysis of a planktonic system off Southern California. Progress in Oceanography 30, 223-251.

Kay, J., Graham, L.A., Ulanowicz, R.E., 1989. A detailed guide for network analysis. In: Wulff, F., Field, J.G., Mann, K.H. (Eds.), Network Analysis in Marine Ecology. Methods and Applications. Springer-Verlag Berlin, 15-61.

Knap, A.H., Michael, A.F., Dow, R.L., Johnson, R.J., Gundersen, K., Sorensen, J.C., Close, A.R., Howse, F.A., Hammer, M., Bates, N., Doyle, A., Waterhouse, T., 1993. BATS Methods Manual. US Joint Global Ocean Flux Planning. Office, Woods Hole Massachusetts, A 3, 1 108.

Knap, A., Michaels, A., Close, A., Ducklow, H., Dickson, A., 1996. Protocols for the Joint Global Ocean Flux Study (JGOFS) Core Measurements, JGOFS Report No. 19, 170 pp. Reprint of the IOC Manuals and Guides No 29, UNESCO 1994.

Kones, J.K., Soetaert, K., van Oevelen, D., Owino, J.O., Mavuti, K., 2006. Gaining insight into food webs reconstructed by the inyerse method. Journal of Marine Systems 60, 153-166.

Lafabrie, C., Hlaili, A.S., Leboulanger, C., Tarhouni, I., Othman, H.B, Mzoughi, N., Chouba, L., Pringault, O., 2013. Contaminated sediment resuspension induces shifts in phytoplankton structure and function in a eutrophic Mediterranean lagoon. Knowledge and Management of Aquatic Ecosystems 410, 1-16.

Lafferty, K.D., Hechinger, R.F., Shaw, J.C., Whitney, K., Kuris, A.M., 2006. Food webs and parasites in salt marsh ecosystem. Chap. 9, Disease ecology: community structure and pathogen dynamics, Oxford University Press, 119-134.

Lafferty, K.D., Allesina, S., Arim, M., Briggs, C.J., Leo, G., 2008. Parasites in food webs: the ultimate missing links. Ecology Letters 11, 533-546.

Landry, M.R., Hassett, R.P., 1982. Estimating the Grazing Impact of Marine Microzooplankton. Marine Biology 67, 283-288.

Leboulanger, C., Bouvy, M., Carre, C., Cecchi, P., Amalric, L., Bouchez, A., Pagano, M., Sarazin, G., 2011. Comparison of the effects of two herbicides and an insecticide on tropical freshwater plankton in microcosms. Archives of Environmental Contamination and Toxicology 61, 599-613.

Legendre, L., Rassoulzadegan, F., 1995. Plankton and nutrient dynamics in marine waters. Ophelia 41, 153-172. 
Legendre, L., Rassoulzadegan, F., 1996. Food-web mediated export of biogenic carbon in oceans: hydrodynamic control. Marine Ecology Progress Series 145, 179-193.

Legendre, L., Rivkin, R.B., 2002. Fluxes of carbon in the upper ocean: regulation by foodweb control nodes. Marine Ecology Progress Series 242, 95-109.

Lorenzen, C. J., 1967. Determination of chlorophyll and pheo-pigments: spectrophotometric equations. Limnology and Oceanography 12, 343-346.

Louati, H., Ben Said, O., Got, P., Soltani, A., Mahmoudi, E., Cravo-Laureau, P., Duran, R., Aissa, P., Pringault, O., 2013. Microbial community responses to bioremediation treatments for the mitigation of low-dose anthracene in marine coastal sediments of Bizerte lagoon (Tunisia). Environtal Science and Pollution Research 20, 300-310.

Lund, J.W.G., Kipling, C., LeCren, E.D., 1958. The inverted microscope method of estimating algal numbers and statistical basis of estimations by counting. Hydrobiologia 11, 143-170.

MacIsaac, E.A., Stockner, J.G., 1993. Enumeration of phototrophic picoplankton by autofluorescence microscopy. In: Kemp, P.F., Sherr, B.F., Sherr, E.B., Cole, J.J. (Eds.), Handbook of Methodology in Aquatic Microbial Ecology. Lewis Publishers, Boca Raton, FL, pp 187-197.

Mackas, D., Bohrer, R., 1976. Fluorescence analysis of zooplankton gut contents and an investigation of diel feeding patterns. Journal of Experimental Marine Biology and Ecology $25,77-85$.

Marquis, E., Niquil, N., Delmas, D., Hartmann, H.J., Bonnet, D., Carlotti, F., Herbland, A., Labry, C., Sautour, B., Laborde, P., Vézina, A., Dupuy, C., 2007. Inverse analysis of the planktonic food web dynamics related to phytoplankton bloom development on the continental shelf of the Bay of Biscay, French coast. Estuarine Coastal and Shelf Science 73, 223-235.

Moigis, A.G., 2000. Photosynthetic rates in the surface waters of the Red Sea: the radiocarbon vs. the non-isotopic dilution method. Journal of Plankton Research 22, 713-727.

Monaco, M.E., Ulanowicz, R.E., 1997. Comparative ecosystem trophic structure of three U.S. mid-Atlantic estuaries. Marine Ecology Progress Series 161, 239-254.

Morales, C.E., Harris, R.P., Head, R.N., Tranter, P.R.G., 1993. Copepod grazing in the oceanic northeast Atlantic during a 6 week drifting station: the contribution of size classes and vertical migrants. Journal of Plankton Research 15, 185-211.

Mzoughi, N., Lespes, G., Bravo, M., Dachraoui, M., Potin-Gautier, M., 2005. Organotin speciation in Bizerte lagoon (Tunisia). Science of the Total Environment 349, 211-222.

Niquil, N., Jackson, G.A., Legendre, L., Delesalle, B., 1998. Inverse model analys is of the planktonic food web of Takapoto Atoll (French Polynesia). Marine Ecology Progress Series $165,17-29$. 
Niquil, N., Bartoli, G., Urabe, J., Jackson, G.A., Legendre, L., Dupuy, C., Kumagai, M., 2006. Carbon steady state model of the planktonic food web of Lake Biwa, Japan. Freshwater Biology 51, 1570-1585.

Niquil, N., Kagami, M., Urabe J, Christaki, U., Viscogliosi, E., Sime-Ngando, T., 2011. Potential role of fungi in plankton food web functioning and stability: a simulation analysis based on Lake Biwa inverse model. Hydrobiologia 659, 65-79.

Niquil, N., Chaumillon, E., Johnson, G.A., Bertin, X., Grami, B., David, V., Bacher, C., Asmus, H., Baird, D., Asmus, R., 2012. The effect of physical drivers on ecosystem indices derived from ecological network analysis: Comparison across estuarine ecosystems. Estuarine Coastal and Shelf Science 108, 132-143.

Niquil, N., Baeta, A., Marques, J.C., Chaalali, A., Lobry, J., Patrício, J., 2014. How does an estuarine food web react to disturbances? Lindeman's perspective Marine Ecology Progress Series 512, 141-154.

Odum, E.P., 1969. The strategy of ecosystem development. Science 164, 262-270.

Parsons, T.P., Maita, Y.,Lalli, C.M., 1984. A manuel of Chemical and Biological Methods for Seawater analysis. Pergamon Press, Oxford, England 1, 173.

Patrício, J., Ulanowicz, R., Pardal, M.A., Marques, J.C., 2004. Ascendency as an ecological indicator: a case study of estuarine pulse eutrophication. Estuarine Coastal and Shelf Science 60, 23-35.

Piroddi, C., Teixeiraa, H., Lynamb, C.P., Smithc, C., Alvarez, M.C., Mazik, K., Andonegi, E., Churilovaf, T., Tedescog, L., Chifflet, M., Chust, G., Galparsoroe, I., Garcia, A.C., Kämäri, M., Kryvenkof, O., Lassallei, G., Neville, S., Niquil, N., Papadopoulou, N., Rossberg, A.G., Suslink, V., Uyarra, M.C., 2015.Using ecological models to assess ecosystem status in support of the European Marine Strategy Framework Directive.Ecological Indicators 58, 175191.

Pomeroy, L. R., 1974. The ocean's food web: A changing paradigm. Bioscience 24, 499-504.

Pringault, O., Lafabrie, C., Avezac, M., Bancon-Montigny, C., Carre, C., Chalghaf, M., Delpoux, S., Duvivier, A., Elbaz-Poulichet, F., Gonzalez, C., Got, P., Leboulanger, C., Spinelli, S., Sakka Hlaili, A., Bouvy, M., 2016. Consequences of contaminant mixture on the dynamics and functional diversity of bacterioplankton in a southwestern Mediterranean coastal ecosystem. Chemosphere 144, 1060-1073.

Proulx, S. R., Promislow, D. E. L., Phillips, P. C., 2005. Network thinking in ecology and evolution. Trends in Ecology and Evolution 20, 345-353.

Rasconi, S., Grami, B., Niquil, N., Jobard, M., \& Sime-Ngando, T., 2014. Parasitic chytrids sustain zooplankton growth during inedible algal bloom. Frontiers in Microbiology 5, 1-19.

Richardson, T.L., Jackson, G.A., Burd, A.B., 2003. Planktonic food web dynamics in two contrasting regions of Florida Bay U S. Bulletin of Marine Science 73, 569-591. 
Richardson, T.L., Jackson, G.A., Ducklow, H.W., Roman, M.R., 2004. Carbon fluxes through food webs of the eastern equatorial Pacific: an inverse approach. Deep Sea Research I 51, 1245-1274.

Saint-Béat, B., Vézina, A.F., Asmus, R., Asmus, H., Niquil, N., 2013.The mean function provides robustness to linear inverse modelling flow estimation in food webs: a comparison of functions derived from statistics and ecological theories. Ecologicol Modeling 258, 53-64.

Saint-Béat, B., Baird, D., Asmus, H., Asmus, R., Bacher, C., Pacella, S.R., Johnson, G.A., David, V., Vézinaf, A.F., Niquil, N., 2015. Trophic networks: How do theories link ecosystem structure and functioning to stability properties? A review. Ecological Indicators $52,458-471$.

Sahraoui, I., Grami, B., Bates, S.S., Bouchouicha, D., Chikhaoui, M.A., Hadj Mabrouk, H., Sakka Hlaili, A., 2012. Response of potentially toxic Pseudo-nitzschia (Bacillariophyceae) populations and domoic acid to environmental conditions in a eutrophied, SW Mediterranean coastal lagoon (Tunisia). Estuarine Coastal and Shelf Science 102-103, 95-104.

Sakka Hlaili, A., Chikhaoui, M.A., Grami, B., Hadj Mabrouk, H., 2006. Effects of N and P supply on phytoplankton in Bizerte Lagoon (western Mediterranean). Journal of Experimental Marine Biology and Ecology 333, 79-96.

Sakka Hlaili, A., Grami, B., Hadj Mabrouk, H., Gosselin, M., Hamel, D., 2007. Phytoplankton growth and microzooplankton grazing rates in a restricted Mediterranean lagoon (Bizerte Lagoon, Tunisia). Marine Biology 151, 767-783.

Sakka Hlaili, A., Grami, B., Niquil, N., Gosselin, M., Hamel, D., Hadj Mabrouk, H., 2008. The Planktonic food web of the Bizerte Lagoon (South-western Mediterranean): I. Spatial distribution under different human pressures. Estuarine Coastal and Shelf Science 78, 61-77.

Sakka Hlaili, A., Niquil, N., Legendre, L., 2014. Planktonic food webs revisited: Reanalysis of results from the linear inverse approach. Progress in Oceanography 120, 216-229.

Scharler, U.M., Baird, D., 2005. A comparison of selected ecosystem attributes of three South African estuaries with different freshwater inflow regimes, using network analysis. Journal of marine system 56, 283-308.

Savenkoff, C., Bourdages, H., Swain, D.P., Despatie, S.P., Hanson, J. M., Méthot, R., Morissette, L., 2004. Input data and parameter estimates for ecosystem models of the southern Gulf of St Lawrence (mid-1980s and mid-1990s). Canadian Technical Report of Fisheries and Aquatic Sciences 2529, 105.

Sherr, E.B., Sherr, B.F., 1988. Role of microbes in pelagic food webs: a revised concept. Limnology and Oceanography 33, 1225-1227.

Sherr, E.B., Sherr, B.F., 1993. Preservation and storage of samples for enumeration of heterotrophic protests. In: Kemp, P.F., Sherr, B.F., Sherr, E.B., Cole, J.J. (Eds.), Handbook of Methods in Aquatic Microbial Ecology. Lewis Publishers, London, pp 207-212. 
Slaughter, A.M., Bollens, S.M., Bollens, G. R., 2006. Grazing impact of mesozooplankton in an upwelling region off northern California, 2000-2003. Deep Sea Research II 53, 3099-3115.

Smayda, T.J., Reynolds, C.S., 2001. Community assembly in marine phytoplankton: application of recent models to harmful dinoflagellate blooms. Journal of Plankton Research $23,447-461$.

Steele, J.H., 1974. The structure of marine ecosystems. Harvard University Press, Cambridge. $128 \mathrm{p}$.

Steinberg, D.K., Carlson, C.A., Bates, N.R. et al., 2000. Zooplankton vertical migration and the active transport of dissolved organic and inorganic carbon in the Sargasso Sea. Deep Sea Research I 47, 137-158.

Tecchio, S., Chaalali, A., Raoux, A., Tous Rius, A., Lequesne, J., Girardin, V., Lassalle, G., Cachera, M., Riou, P., Lobry, J., Dauvin, J.C., Niquil, N., 2016. Evaluating ecosystem-level anthropogenic impacts in a stressed transitional environment: The case of the Seine estuary. Ecological Indicators 61, 833-845.

Tecchio, S., Coll, M., Christensen, V., Company, J.B., Ramírez-Llodra, E., Sardà, F., 2013. Food web structure and vulnerability of a deep-sea ecosystem in the NW Mediterranean Sea. Deep Sea Research I 75, 1-15.

Teira, E., Albade, J., Alvarez-Ossorio, M., Bode, A., Carino, C., Cid, A., Fernandez, E., Gonzalez, N., Lorenzo, J., Valencia, J., Varela, M., 2003. Plankton carbon budget in a coastal wind-driven upwelling station off a Coruna (NW Iberian Peninsula). Marine Ecology Progress Series 265, 31-43.

Thomas, C.R., Christian, R.R., 2001. Comparison of nitrogen cycling in salt marsh zones related to sea-level rise. Marine Ecology Progress Series 221, 1-16.

Tortajada, S., Niquil, N., Blanchet, H., Grami, B., Montanie, H., David, V., Gle, C., SaintBeat, B., Johnson, G.A., Marquis, E., Del Amo, Y., Dubois, S., Vincent, D., Dupuy, C., Jude, F., Hartmann, H.J., Sautour, B., 2012. Network analysis of the planktonic food web during the spring bloom in a semi enclosed lagoon (Arcachon, SW France). Acta Oecologica 40, 40-50.

Trabelsi, S., Driss, M. R., 2005. Polycyclic aromatic hydrocarbons in superficial coastal sediments from Bizerte Lagoon, Tunisia. Marine Pollution Bulletin 50, 344-349.

Ulanowicz, R.E., 1980. An hypothesis on the development of natural communities. Journal of Theoretical Biology 85, 223-245.

Ulanowicz, R.E., 1986. Growth and Development: Ecosystems Phenomenology. SpringerVerlag, New York. 
Ulanowicz, R.E., Wulff, F., 1991. Comparing ecosystem structures: the Chesapeake Bay and the Baltic Sea. In: Cole J, Lovett G, Findlay S (eds) Comparative analyses of ecosystems, pattern, mechanlsrn, and theories. Springer-Verlag New York, 140-166.

Ulanowicz, R.E., 1996. Trophic flow networks as indicators of ecosystem stress. In: Polis GA,Winemiller KO, Eds. Foodwebs: integration of patterns and dynamics New York. Chapman and Hall, 358-68.

Ulanowicz, R.E., 1997. Ecology, the Ascendent Perspective Columbia University Press, New York.

Ulanowicz, R.E., 2000. Ascendency: a measure of ecosystem performance. In: Jørgensen, S.E., Müller, F. (Eds.), Handbook of Ecosystem Theories and Management. Boca Raton, 303316.

Ulanowicz, R.E., 2004. Quantitative methods for ecological network analysis. Computational Biology and Chemistry 28, 321-339.

Ulanowicz, R.E., Goerner, S.J., Lietaer, B., Gomez, R., 2009. Quantifying sustainability: resilience, efficiency and the return to of information theory. Ecological complexity 6, 27-36.

Umani, S.F., Beran, A., 2003. Seasonal variations in the dynamics of microbial plankton communities: first estimates from experiments in the Gulf of Trieste, Northern Adriatic Sea. Marine Ecology Progress Series 247, 1-16.

Utermöhl, H., 1958. Zur Vervollkommnung der quantitativen Phytoplankton methodik. Mitteilungen der Internationalen Vereinigung für Theoretische und Ange wandte Limnologie 9, 1-38.

Van den Meersche, K., Soetaert, K., Van Oevelen, D., 2009. xsample(): An R Function for Sampling Linear Inverse Problems. Journal of Statistical Software 30, 1-15.

Vasconcellos, M., Mackinson, S., Sloman, K., Pauly, D., 1997. The stability of trophic massbalance models of marine ecosystems: a comparative analysis. Ecological Modelling 100, 125-134.

Vassallo, P., Fabiano, M., Vezzulli, L., Sandulli, R., Marques, J.C., Jørgensen, S.E., 2006.Assessing the health of coastal marine ecosystems: A holistic approach based on sediment micro and meio-benthic measures. Ecological Indicators 6, 525-542.

Vézina, A.F., Platt, T., 1988. Food web dynamics in the ocean. I. Best estimates using inverse Methods. Marine Ecology Progress Series 42, 269-287.

Vézina, F.A., Demers, S., Laurion, I., Sime-Ngando, T., Juniper, S.K., Devine, L., 1997. Carbon flows through the microbial food web of first-year ice in Resolute Passage (Canadian High Arctic). Journal of Marine Systems, 173-189.

Vézina, A.F., Savenkoff, C., Roy, S., Klein, B., Rivkin, R., Therriault, J.C., Legendre, L., 2000. Export of biogenic carbon and structure and dynamics of the pelagic food web in the Gulf of St Lawrence Part 1 Seasonal variations. Deep Sea Research II 47, 585-607. 
Vézina, A.F., and Pahlow, M., 2003. Reconstruction of ecosystem flows using inverse methods: how well do they work?. Journal of Marine Systems40, 55-77.

Weinbauer, M.G., Winter, C., Höfle, M.G., 2002. Reconsidering transmission electron microscopy based estimates of viral infection of bacterioplankton using conversion factors derived from natural communities. Aquatic Microbiol Ecology 27, 103-110.

Zmerli Triki, H., Laabir, M., Lafabrie, C., Malouche, D., Bancon-Montigny, C., Gonzalez, C., Deidun, A., Pringault, O., Kéfi Daly-Yahia, O., 2017. Do the levels of industrial pollutants influence the distribution and abundance of dinoflagellate cysts in the recently-deposited sediment of a Mediterranean coastal ecosystem?. Science of the Total Environment 595, 380392.

Zrafi-Nouira, I., Khedir-Ghenim, Z., Zrafi, F., Bahri, R., Cheraeif, I., Rouabhia, M., 2008. Hydrocarbon pollution in the sediment from the Jarzouna-Bizerte coastal area of Tunisia (Mediterranean Sea). Bulletin of Environmental Contamination and Toxicology 80, 566-572. 


\section{Figure captions}

Figure 1.Location of the study stations (L, C and B) in the Lagoon, the Channel and the Bay of Bizerte.

Figure 2. A priori model for the studied networks. Heterotrophic bacteria $=$ bac, picophytoplankton $<2 \mu \mathrm{m}=$ pic, nanophytoplankton $2-10 \mu \mathrm{m}=$ nan, microphytoplankton 20-200 $\mu \mathrm{m}=$ mic, protozooplankton $<200 \mu \mathrm{m}=$ pro, metazooplankton $200-700 \mu \mathrm{m}=$ met 1 , metazooplankton $>700 \mu \mathrm{m}=$ met 2 , dissolved organic carbon $=$ doc and detritus $=$ det.

Figure 3. Interval of possible values $\left(\mathrm{mg} \mathrm{C} \mathrm{m}^{-2} \mathrm{~d}^{-1}\right)$ for main flows derived from the inverse analysis solution for the Lagoon, the Channel and the Bay of Bizerte during spring 2012.

Figure 4. Carbon output driven by respiration (A) and vertical sinking and doc loss (B) from each considered compartment for the three studied sites. The error bars represent the $95 \%$ confidence interval calculated from the probability distribution of each flow. For each flow the confidence interval was calculated for 300000 solutions.

Figure 5. Throughput of each compartment for the three models in the study sites. The error bars represent the $95 \%$ confidence interval calculated from the probability distribution of each flow.For each flow the confidence interval was calculated for 300000 solutions.

Figure 6. Exudation and excretion (flows to doc) (A) and detritus production (flows to det) (B) driven by each compartment for the three models in the study sites. The error bars represent the $95 \%$ confidence interval calculated from the probability distribution of each flow.For each flow the confidence interval was calculated for 300000 solutions.

Figure 7. Diet of protozooplankton (A) and two size classes of metazooplankton [200$700 \mu \mathrm{m}(\mathrm{B})$, and $>700 \mu \mathrm{m},(\mathrm{C})]$ in the three study sites.

Figure 8. Comparison of Ecological Network indices calculated for the three planktonic food webs. Total system throughput (TST): $\mathrm{mg} \mathrm{C} \mathrm{m}^{-2} \mathrm{~d}^{-1}$, Development Capacity (DC) and Ascendency (A): $\mathrm{mg} \mathrm{C} \mathrm{m}^{-2} \mathrm{~d}^{-1}$, bits, Average Path Length (APL): no unit, Finn Cycling Index (FCI) and A/DC: \%. The error bars represent the 95\% confidence interval calculated from the probability distribution of each flow. Asterisks indicate comparisons that were considered significant (small $(*)$ medium $(* *)$ and large effects $(* * *)$ ) using Cliff's $\boldsymbol{\delta}$ for the comparisons: a-Lagoon-Channel; b-Channel-Bay and c- Lagoon-Bay of Bizerte during spring 2012. 


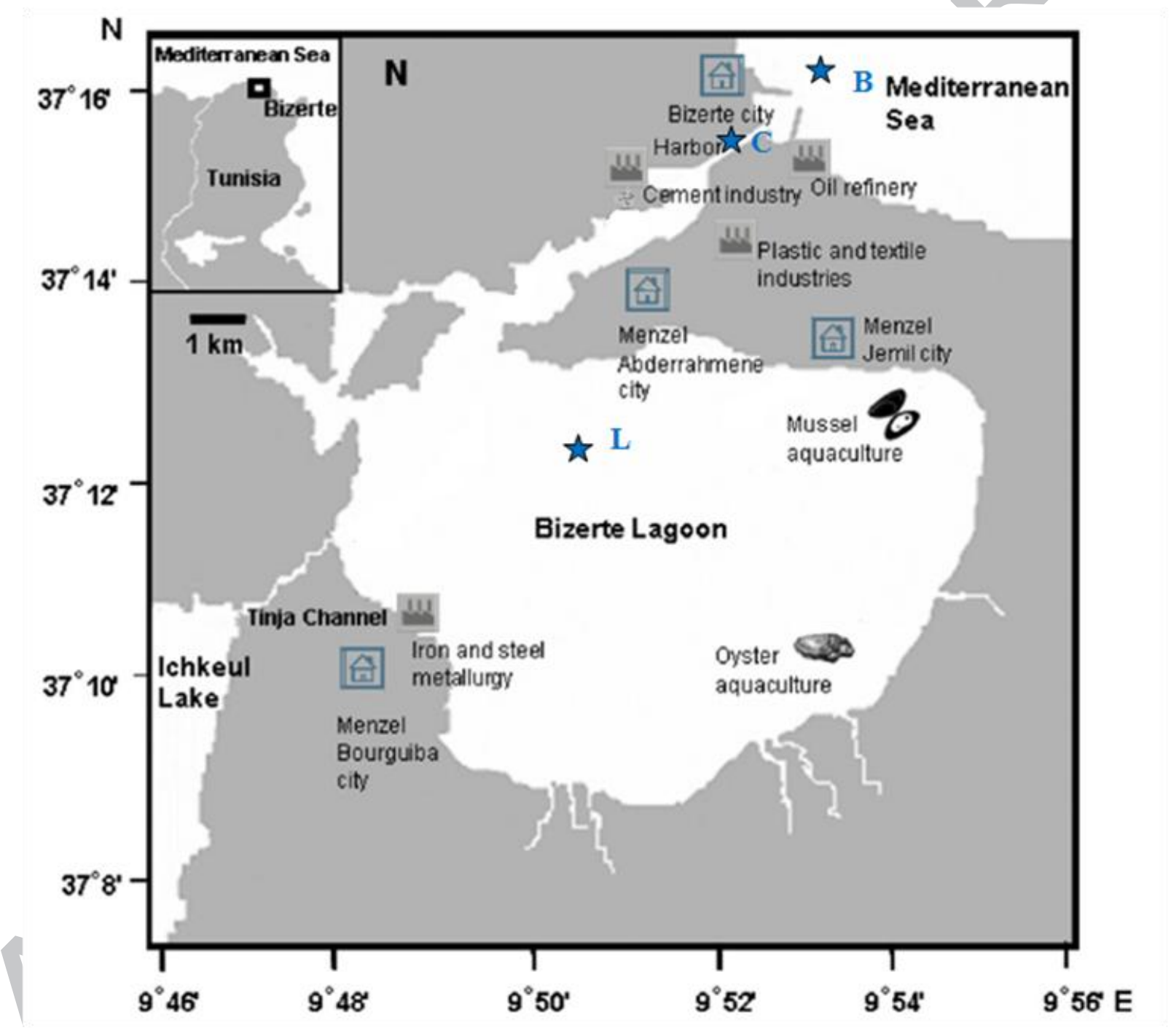

Fig. 1 


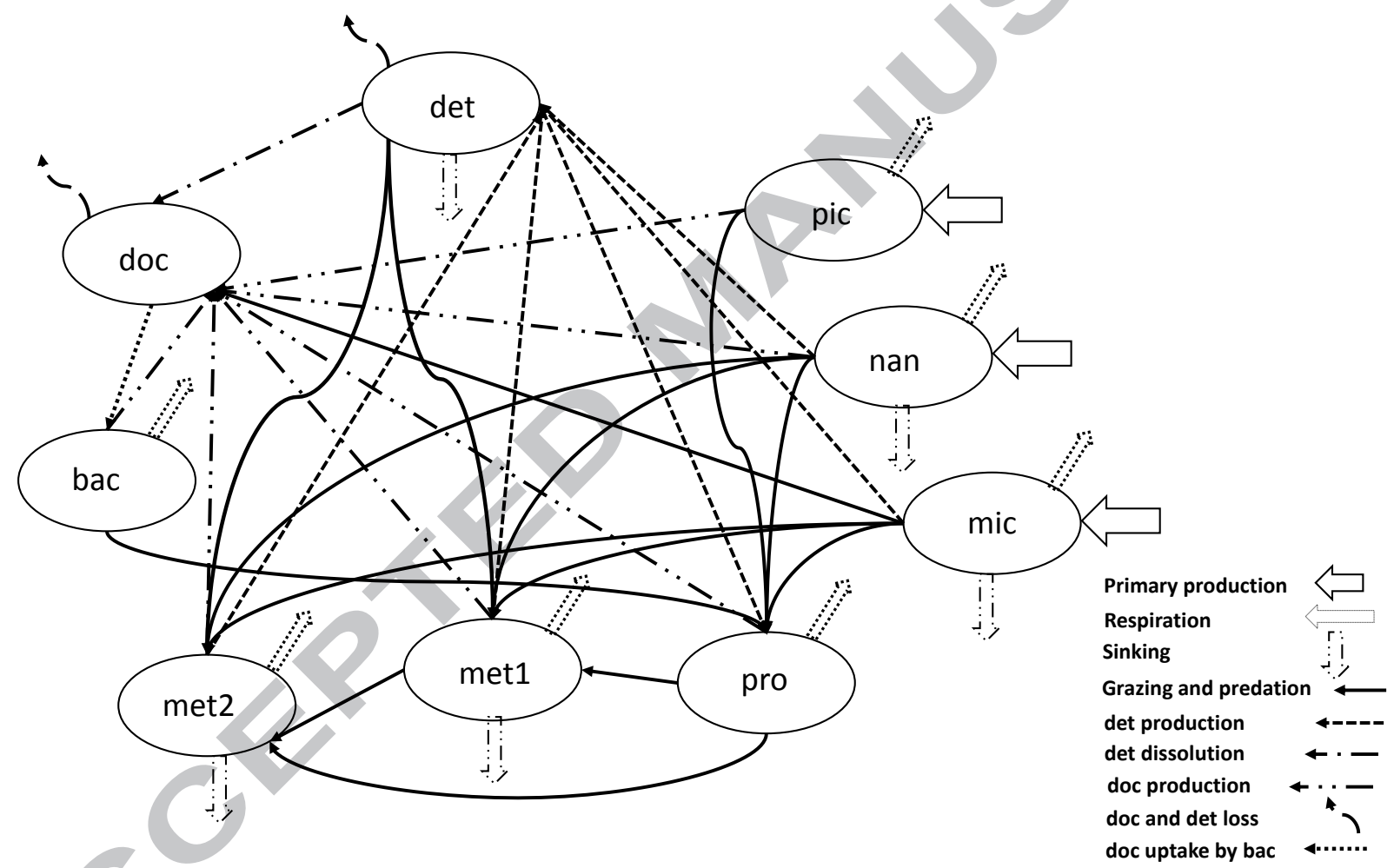

Fig. 2 


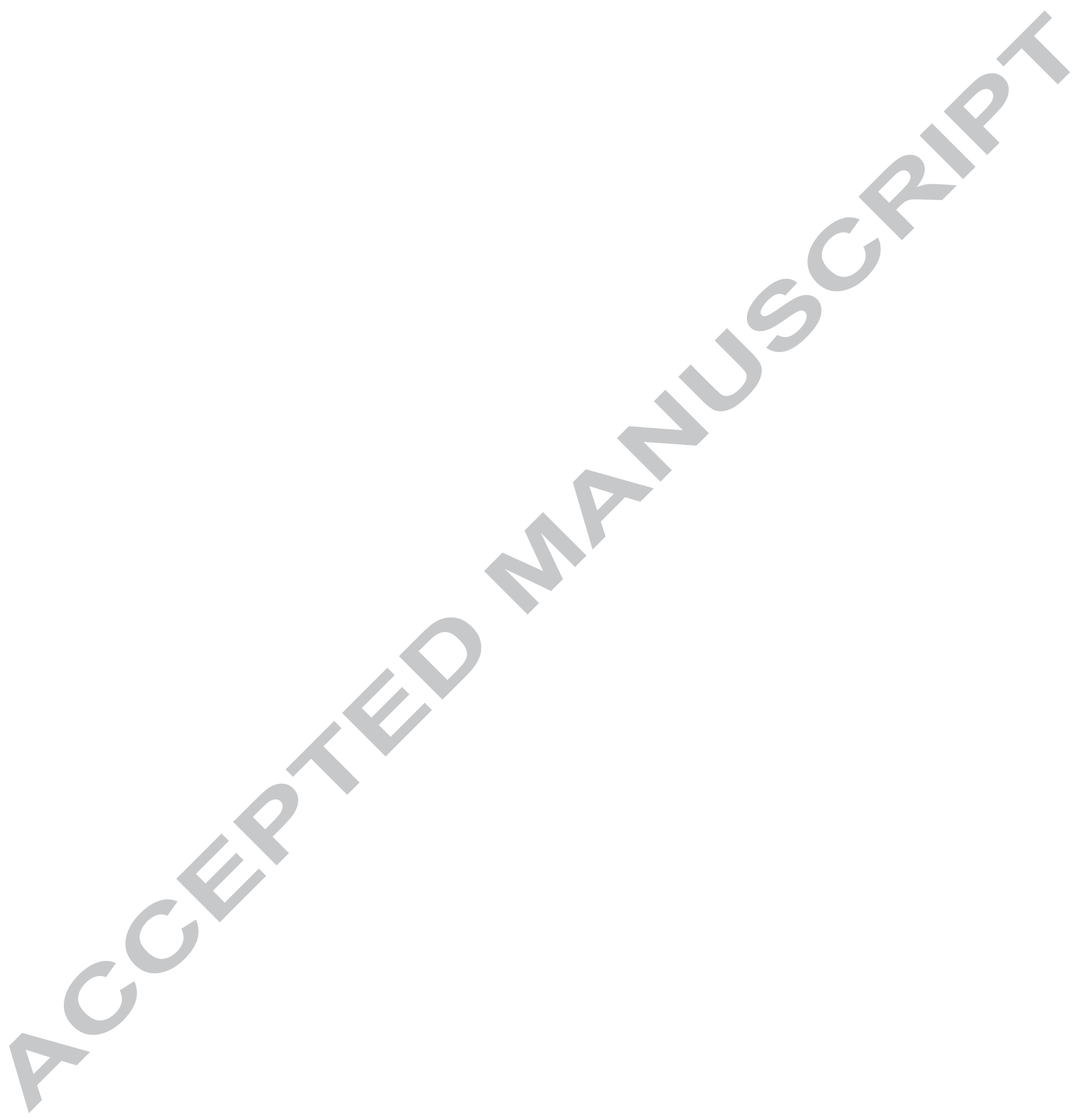


A- Lagoon (inshore)

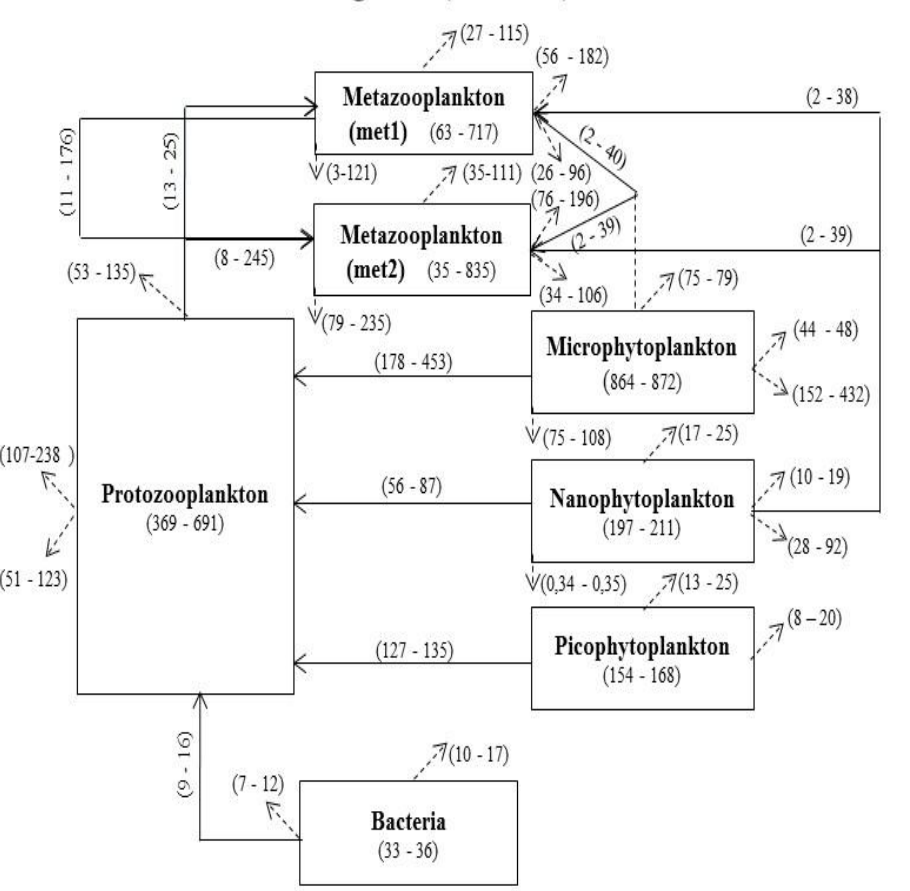

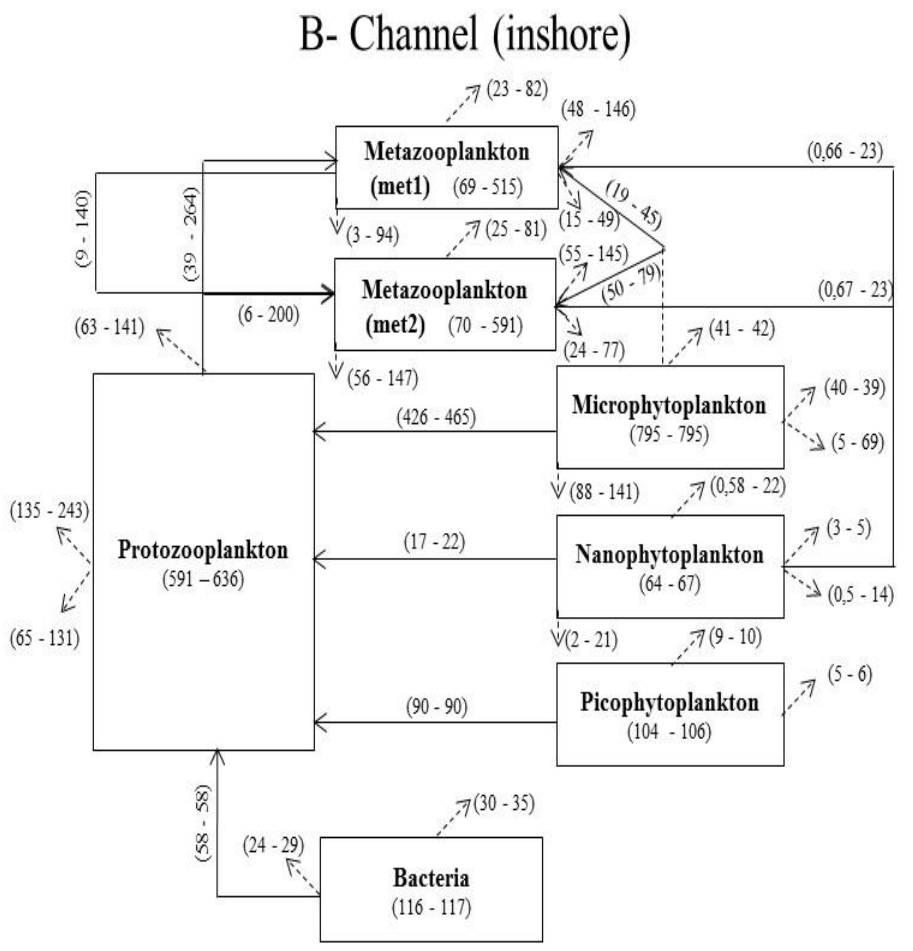

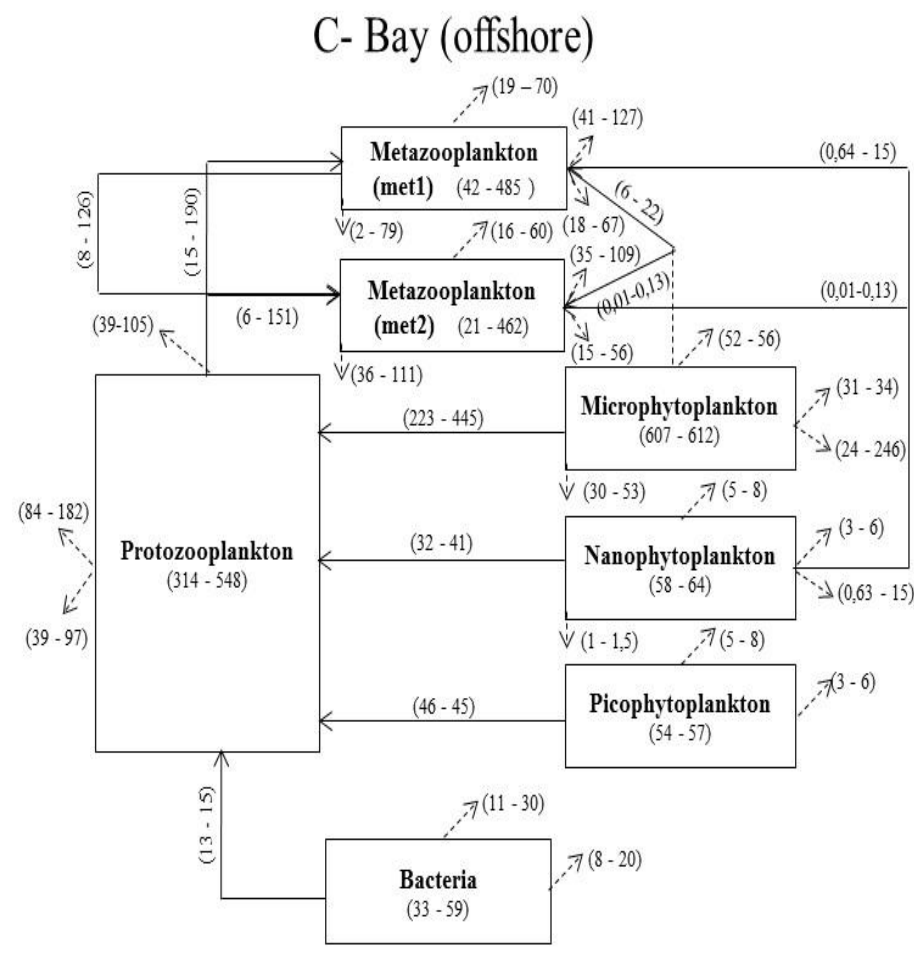

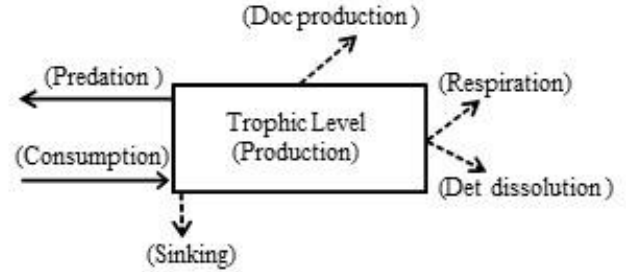

(flux $\mathrm{mgC} \mathrm{m}^{-2} \mathrm{~d}^{-1}$ )

Fig. 3 


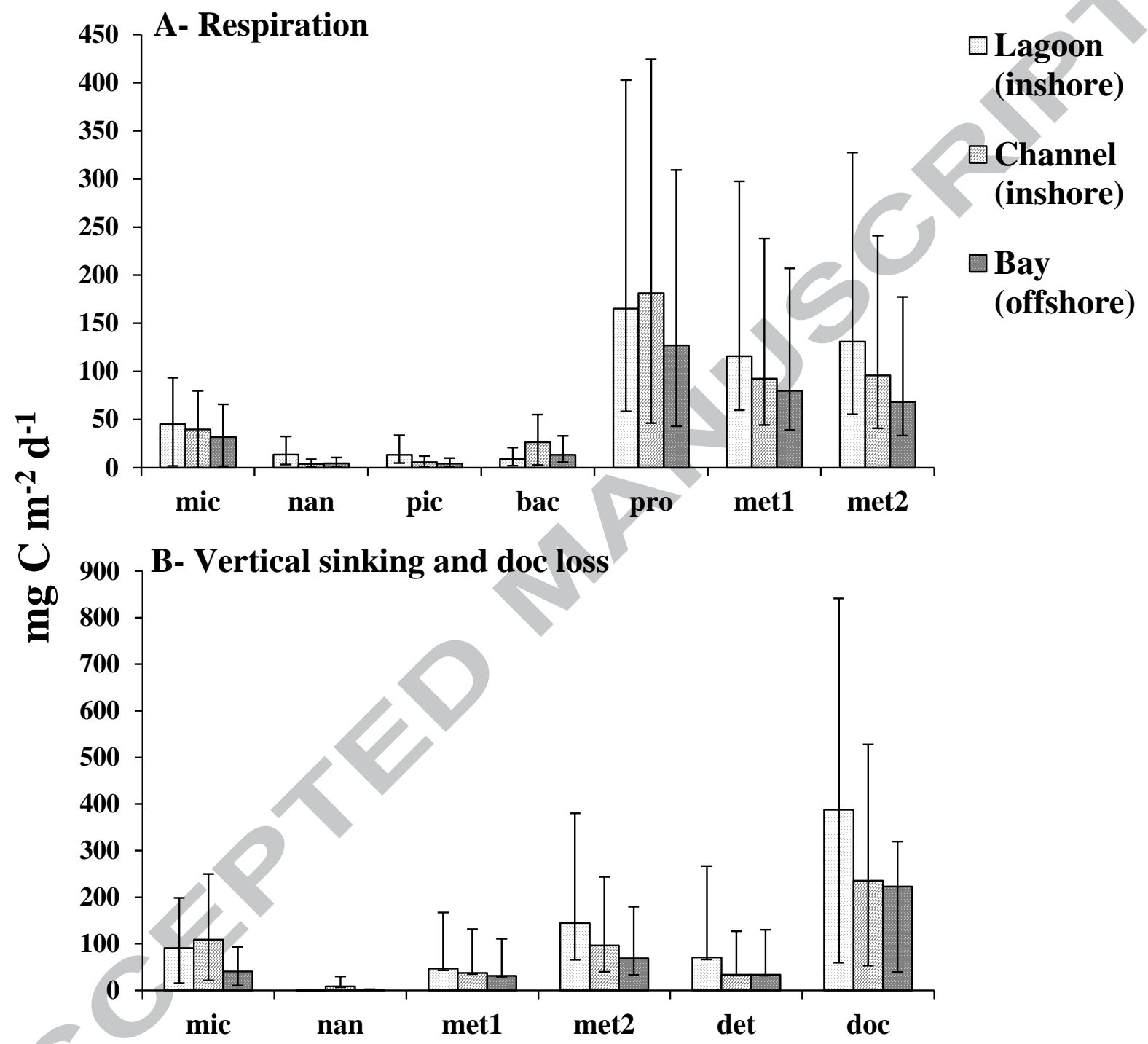

Fig. 4

6

7

8

9 


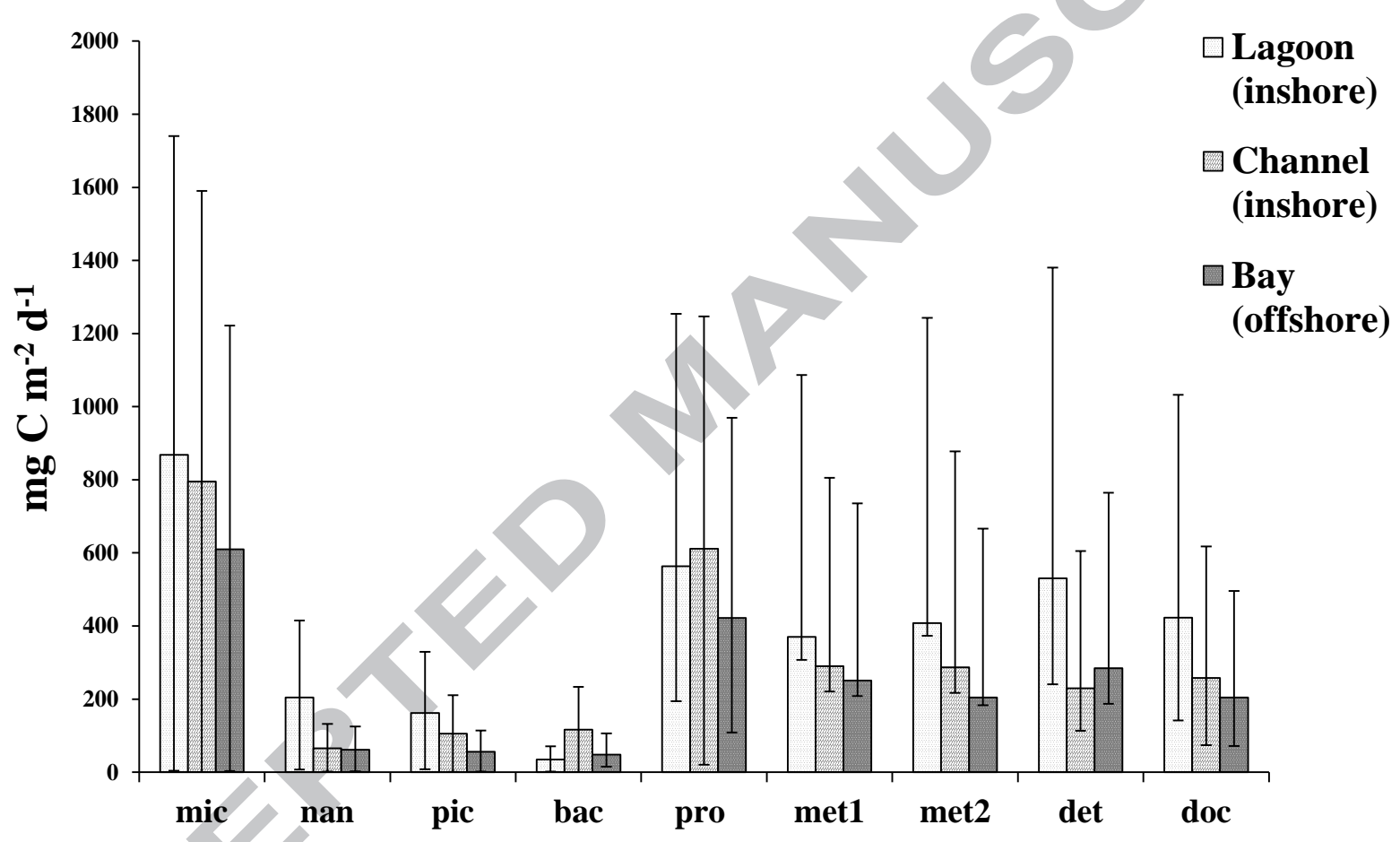

Fig. 5 


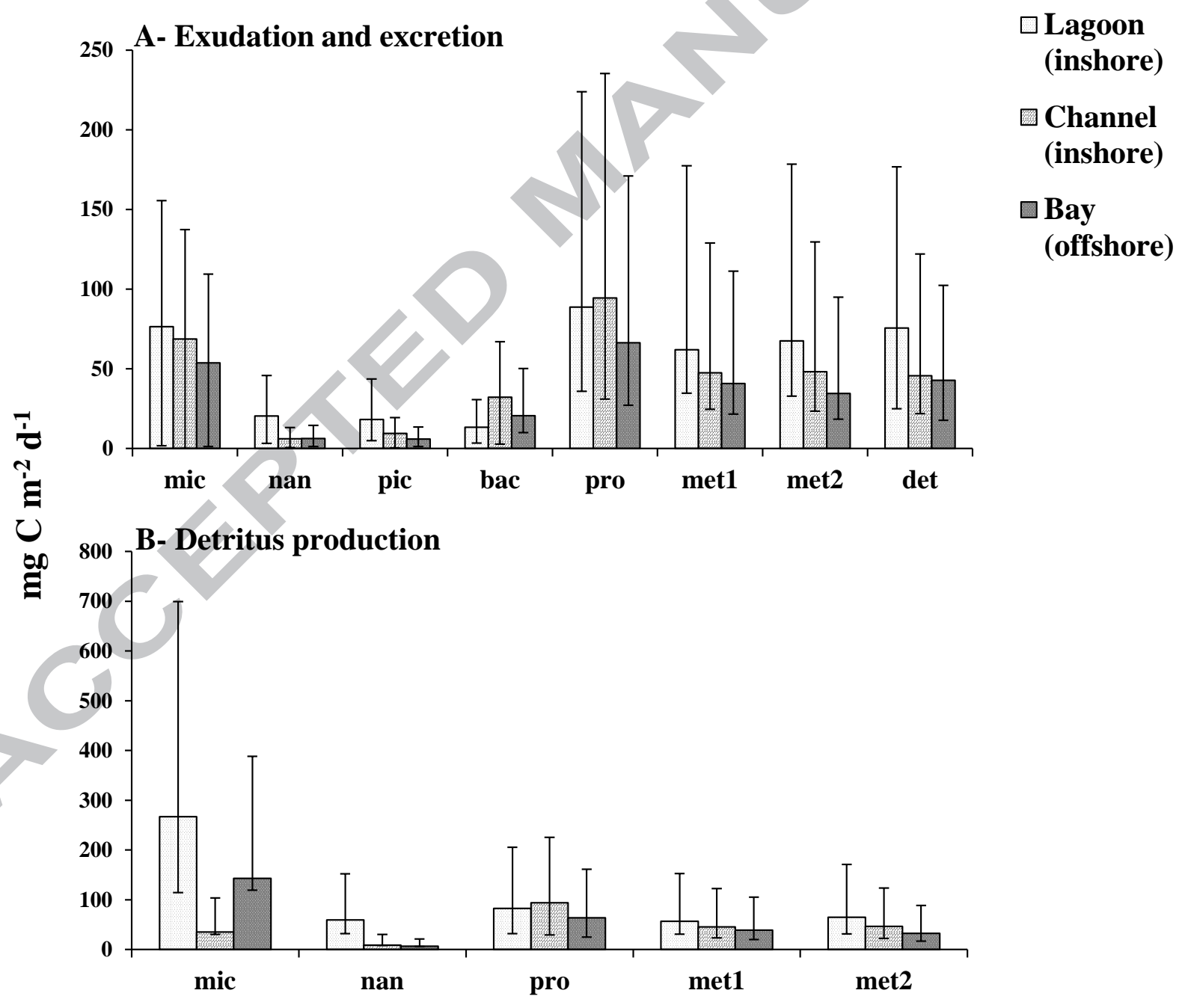


41

42

43

44

45

46

47

48 
A- Protozooplankton $(<200 \mu \mathrm{m})$
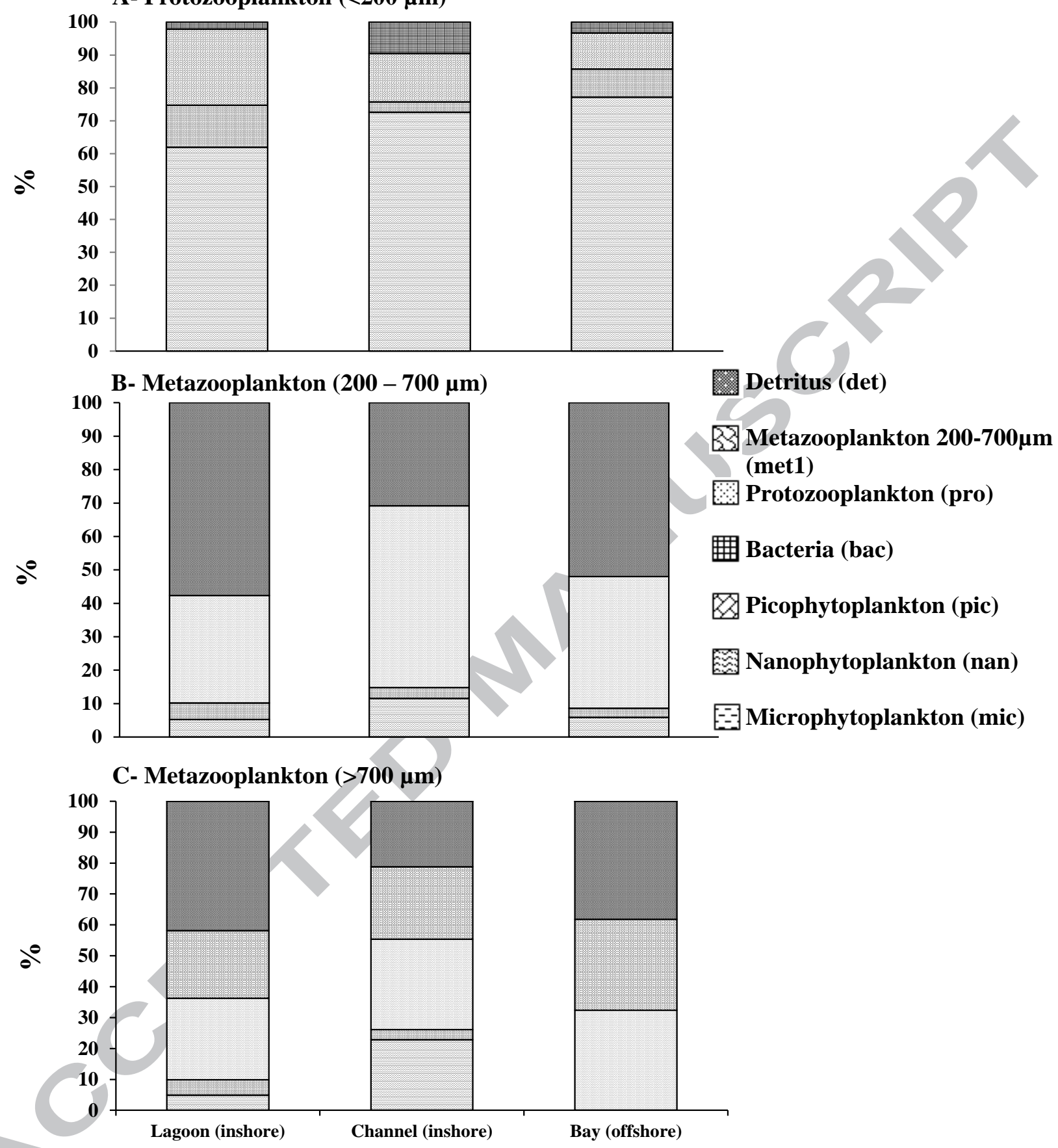
60
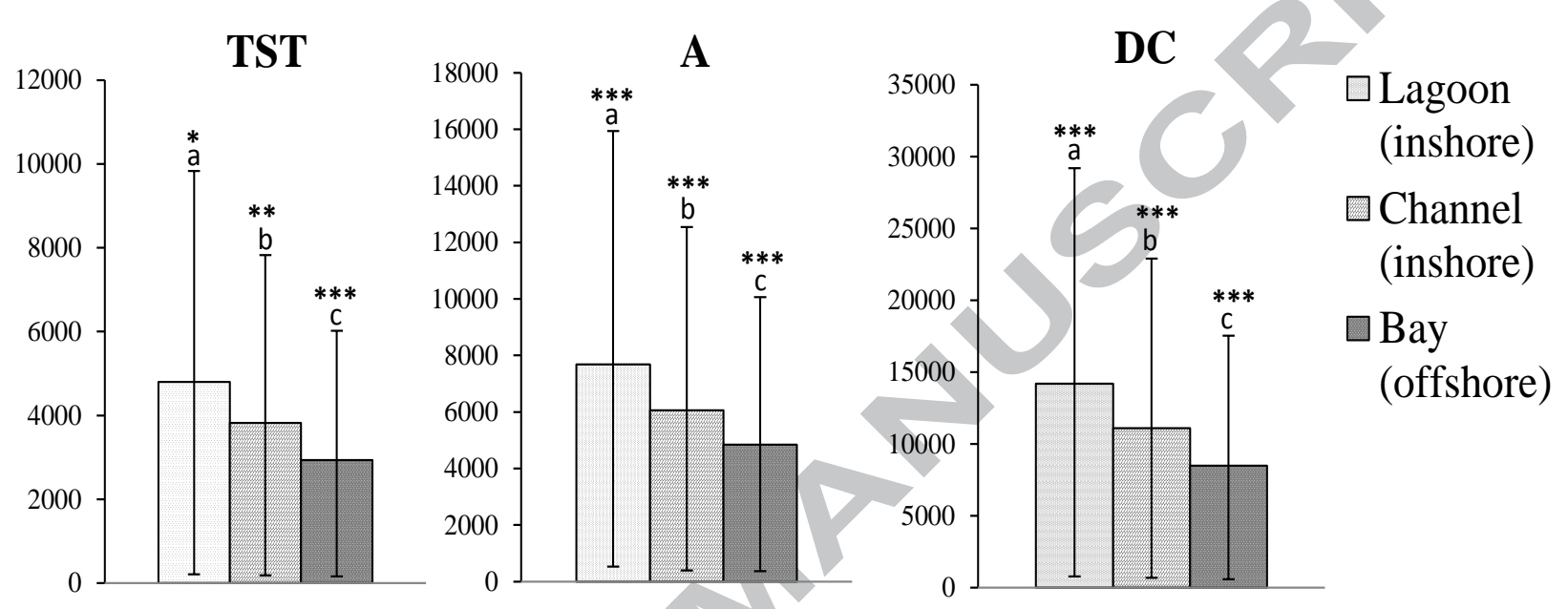

61

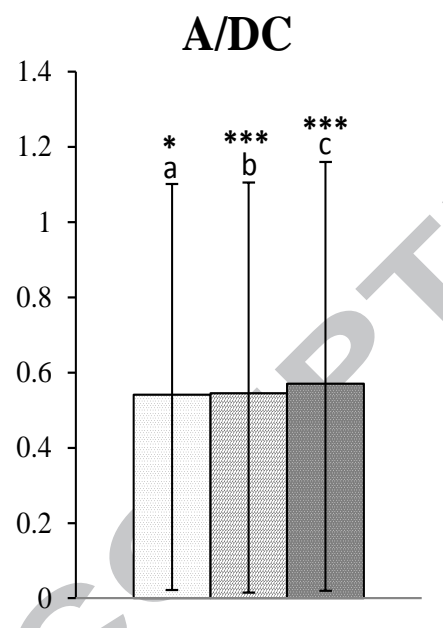

APL

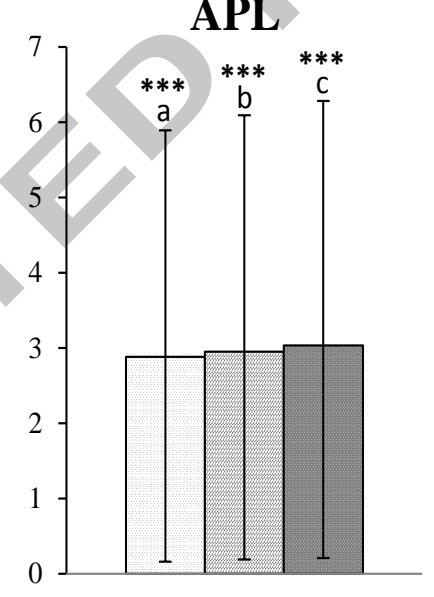

FCI

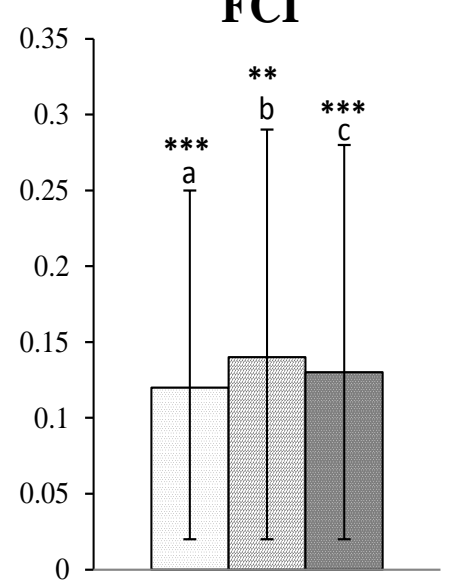

62

Fig. 8 
Table 1. Summary list of factors and formulae used to convert biovolumes to carbon biomasses for plankton organisms.

\begin{tabular}{|c|c|c|}
\hline Plankton & Conversion factors or formulae & Reference \\
\hline Bacteria & $0.35 \mathrm{pg} \mathrm{C} \mu \mathrm{m}^{-3}$ & Bjørnsen, 1986 \\
\hline Procaryotic picophytoplankton & $0.22 \mathrm{pg} \mathrm{C} \mu \mathrm{m}^{-3}$ & Søndergaard et al., 1991 \\
\hline Eukaryotic picophytoplankton & $0.22 \mathrm{pg} \mathrm{C} \mathrm{cell}^{-1}$ & Mullin et al., 1966 \\
\hline Diatoms & pg C cell ${ }^{-1}=0.288 \times \mathrm{V}^{0.288}$ & Menden-Deuer and Lessard, 2000 \\
\hline Autotrophic flagellates and dinoflagellates & pg C cell ${ }^{-1}=0.216 \times Z^{0.939}$ & Menden-DeuerandLessard, 2000 \\
\hline Ciliates & $0.19 \mathrm{pg} \mathrm{C} \mu \mathrm{m}^{-3}$ & Putt and Stoecker, 1989 \\
\hline Heterotrophic flagellates & $0.15 \mathrm{pg} \mathrm{C} \mu \mathrm{m}^{-3}$ & Sheldon et al., 1986 \\
\hline Copepods & $\mu \mathrm{g} \mathrm{C}$ ind $^{-1}=40 \%$ of DW & Feller and Warwick, 1988 \\
\hline Copepod nauplii & $0.50 \mathrm{pg} \mathrm{C} \mu \mathrm{m}^{-3}$ & Shinada et al., 2003 \\
\hline Cladocera & $\mu \mathrm{g} \mathrm{C}$ ind $^{-1}=5.24 \times \mathrm{L}-1.08$ & Shinada et al., 2003 \\
\hline Molluscan larvae & $\mu \mathrm{g} \mathrm{C}$ ind $^{-1}=\mathrm{WW} \times 0.22$ & Omori, 1969 \\
\hline Other larvae & $0.1 \mathrm{~cm}^{-3}$ of DV corresponds to $10 \mathrm{mg}$ of $\mathrm{C}$ & Harris et al., 2000 \\
\hline Appendicularians & $\operatorname{mg~C}$ ind $^{-1}=\exp [\log C] / 1000$ & King et al., 1980 \\
\hline Others groups & $\mathrm{mg} \mathrm{C} \mathrm{m}{ }^{-3}=\mathrm{CW} x$ ind. $\mathrm{m}^{-3}$ & Omori, 1969 \\
\hline
\end{tabular}


67 Abbreviations: $\mathrm{V}$ is the plasma volume $\left(\mu \mathrm{m}^{-3}\right) ; \mathrm{Z}$ is the cell volume $\left(\mu \mathrm{m}^{-3}\right)$; $\mathrm{L}$ is the length (mm); DW is the dry weight (mg); WW is the wet weight $(\mathrm{mg}) ; \mathrm{DV}$ is the dry volume $\left(\mathrm{cm}^{3}\right) ; \log \mathrm{C}=2.627 \log (\mathrm{L})-7.135 ; \mathrm{CW}$ is the carbon wet weight $\left(\mathrm{mg} \mathrm{C}\right.$ ind $\left.^{-1}\right)$.

Table 2. Mass equilibrium defining linear equations used for the inverse analysis. Flow names in the LIM-MCMC were composed of the threeletter code of the compartment of origin followed by the three-letter code of the destination compartment. Abbreviations: see table content for the compartments, gpp = gross primary production, res $=$ respiration, los $=$ loss for the considered system .

\begin{tabular}{|c|c|c|}
\hline Compartment & Mass balance equation & Equations common to the three models \\
\hline pic & Mass balance for picophytoplankton & gpp-pic $-($ pic-res + pic-doc + pic-pro $)=0$ \\
\hline nan & Mass balance for nanophytoplankton & gpp-nan $-($ nan-res + nan-doc + nan-det + nan-pro + nan-met $1+$ nan-met $2+$ nan-los $)=0$ \\
\hline mic & Mass balance for microphytoplankton & gpp-mic $-($ mic-res + mic-doc + mic-det + mic-pro + mic-met $1+$ mic-met $2+$ mic-los $)=0$ \\
\hline pro & Mass balance for protozooplankton & $($ pic-pro + nan-pro + mic-pro + bac-pro $)-($ pro-res + pro-doc + pro-det + pro-met $1+$ pro-los $)=0$ \\
\hline met1 & Mass balance for metazoans $200-700 \mu \mathrm{m}$ & $($ nan-met $1+$ mic-met $1+$ pro-met $1+$ bac-met 1$)-($ met $1-$ res + met $1-$ doc + met $1-\operatorname{det}+\operatorname{met} 1-\operatorname{met} 2+\operatorname{met} 1-\mathrm{los})=0$ \\
\hline met2 & Mass balance for metazoans $>700 \mu \mathrm{m}$ & $($ nan-met $2+$ mic-met $2+$ pro-met $2+$ met $1-$ met $2+$ det-met 2$)-($ met $2-$ res + met $2-\operatorname{doc}+\operatorname{met} 2-\operatorname{det}+\operatorname{met} 2-\operatorname{los})=0$ \\
\hline bac & Mass balance for bacteria & doc-bac $-($ bac-res + bac-doc + bac-pro $)=0$ \\
\hline doc & Mass balance for dissolved organic carbon & $($ pic-doc + nan-doc + mic-doc + pro-doc + met $1-$ doc + met $2-$ doc + bac-doc + det-doc $)-($ doc-bac + doc-los $)=0$ \\
\hline poc & Mass balance for particulate organic carbon & $($ nan-det + mic-det + pro-det + met $1-\operatorname{det}+\operatorname{met} 2-\operatorname{det})-($ det-doc $+\operatorname{det}-m e t 1+\operatorname{det}-m e t 2+\operatorname{det}-1 o s)=0$ \\
\hline
\end{tabular}


Table 3.Calculated flows $\left(\mathrm{mg} \mathrm{Cm}^{-2} \mathrm{~d}^{-1}\right)$ derived from in situ estimations used as inequalities for the inputs of the three networks.

\begin{tabular}{lllll} 
& & Lagoon Model & Channel Model & Bay Model \\
\hline Flux & Processintegrated as inequalities & & Minimum - Maximum & \\
\hline gpp-pic & pic gross primary production & $126.17-204.37$ & $54.33-76.76$ & $45.92-68.94$ \\
gpp-nan & nan grossprimary production & $284.50-205.56$ & $87.60-120.99$ & $48.25-74.51$ \\
gpp-mic & mic gross primary production & $743.50-993.80$ & $686.74-903.77$ & $521.60-697.79$ \\
pic-pro & pic grazing by protozooplankton & $86.92-135.52$ & $17.02-22.16$ & $30.94-46.49$ \\
nan-pro & nan grazing by protozooplankton & $54.24-88.52$ & $72.51-90.38$ & $31.33-41.49$ \\
mic-pro & micgrazing by protozooplankton & $125.04-460.41$ & $424.55-468.37$ & $209.86-477.51$ \\
doc-bac & bacterial production & $32.87-135.15$ & $89.73-116.92$ & $20.33-59.45$ \\
bac-pro & bacterial grazing by protozooplankton & $8.49-25.09$ & $58.05-60.98$ & $12.70-15.61$ \\
mic-los & mic sinking & $73.68-109.92$ & $86.08-521.36$ & $28.82-54.52$ \\
nan-los & nan sinking & $0.34-0.36$ & $1.42-43.78$ & $0.94-1.47$ \\
mic+nan-met1 & mic and nan consumption by met1 & $23.70-48.80$ & $36.42-49.45$ & $17.44-25.53$ \\
mic+nan-met2 & mic and nan consumption by met2 & $35.79-44.28$ & $65.75-85.11$ & $0.12-0.16$ \\
met1+met2-los & met1 and met2 sinking & $54.18^{*}$ & $15.82^{*}$ & $20.68 *$ \\
det-los & detritus sinking & $3069.31 * *$ & $2361.29 * *$ & $656.68^{* *}$ \\
\hline
\end{tabular}

gpp is gross primary production, los is sinking of particles

* Flows considered as minimum

** Flows considered as maximum 
85 Table 4. Constraints (inequalities) used for the three networks based on literature (L: Lagoon; C: Channel; B: Bay)

\begin{tabular}{|c|c|c|c|c|c|c|}
\hline Process & $\begin{array}{c}\text { Concerned } \\
\text { compartment }\end{array}$ & Bound & Description & Equation & Applied to model & Reference \\
\hline \multirow{4}{*}{ Respiration } & \multirow{2}{*}{ pic. nan. mic } & Lower & $\begin{array}{l}\begin{array}{l}\text { Autotroph respiration(r)is higher than } 5 \% \\
\text { production(gpp) }\end{array} \\
\end{array}$ & $5 \% \mathrm{gpp}<\mathrm{r}$ & L. C and B & \multirow[t]{2}{*}{ Vézina and Platt (1988) } \\
\hline & & Upper & Autotroph respiration is no more than $30 \%$ of gross primary production & $\mathrm{R}<30 \% \mathrm{GPP}$ & L. C and B & \\
\hline & bac & Lower & Bacteria respiration(r')is higher than $20 \%$ of total uptake of doc(udoc) & $20 \%$ udoc $<\mathrm{r}^{\prime}$ & L. C and B & Vézina and Savenkoff (1999) \\
\hline & pro. met1. met2 & Lower & $\begin{array}{|lllllll|}\begin{array}{l}\text { Zooplankton respiration(r')is } \\
\text { ingestion( }(\Sigma \operatorname{Ing})\end{array} & \text { at least } & 20 \% & \text { of } & \text { their total } \\
\end{array}$ & $20 \% \Sigma$ Ing $<\mathrm{r}^{\prime}$ & L. C and B & Vézina and Savenkoff (1999) \\
\hline \multirow{5}{*}{$\begin{array}{l}\text { Dissolved organic } \\
\text { carbon production }\end{array}$} & \multirow{2}{*}{ pic. nan. mic } & Lower & $\begin{array}{l}\text { Autotroph doc exudation(e)is higher than } 10 \% \text { of their net primary } \\
\text { production (npp) }\end{array}$ & $10 \%$ npp<e & L. C and B & \multirow{2}{*}{ Vézina and Savenkoff (1999) } \\
\hline & & Upper & $\begin{array}{l}\text { Autotroph doc exudation(e)doesn't exceed } 55 \% \text { of their net primary } \\
\text { production (npp) }\end{array}$ & e $<55 \%$ npp & L. C and B & \\
\hline & \multirow{2}{*}{ pro. met1. met2 } & Lower & Zooplankton excretion(ex)of doc is at least $10 \%$ of their total ingestion & $10 \% \Sigma$ Ing $<\mathrm{ex}$ & L. C and B & Vézina and Pace (1994) \\
\hline & & Upper & Zooplankton excretion(ex) doesn't exceed their respiration(r") & ex<r' & L. C and B & Vézina and Platt (1988) \\
\hline & bac & Upper & Bacteria doc release (re)is lower than their respiration(r') & re $<\mathrm{r}^{\prime}$ & L. C and B & Vézina and Pace (1994) \\
\hline \multirow{4}{*}{ Growth efficiency } & \multirow{2}{*}{ pro. met1. met2 } & Lower & $\begin{array}{l}\text { The growth efficiency of zooplankton is at least } 25 \% \text { of their carbon } \\
\text { uptake }\end{array}$ & $25 \% \Sigma$ Ing $<$ Ing $-\left(\mathrm{r}^{\prime \prime}+\mathrm{ex}+\mathrm{det}\right)$ & L. C and B & Vézina and Pahlow (2003) \\
\hline & & Upper & $\begin{array}{l}\text { The growth efficiency of zooplankton is no more than } 50 \% \text { of their } \\
\text { carbon uptake }\end{array}$ & Ing $-\left(\mathrm{r}^{\prime \prime}+\mathrm{ex}+\mathrm{det}\right)<50 \% \Sigma$ Ing & L. C and B & Vézina and Pahlow (2003) \\
\hline & \multirow[b]{2}{*}{ bac } & Lower & Growth efficiency of bacteria is at least $5 \%$ of their total ingestion & $5 \%$ udoc <udoc $-\left(\mathrm{r}^{\prime \prime}+\mathrm{re}\right)$ & L. C and B & Vézina and Pahlow (2003) \\
\hline & & Upper & $\begin{array}{l}\text { Growth efficiency of bacteria is no more than } 50 \% \text { of their total } \\
\text { ingestion }\end{array}$ & udoc $-\left(\mathrm{r}^{\prime \prime}+\mathrm{re}\right)<50 \%$ udoc & L. C and B & Vézina and Pahlow (2003) \\
\hline \multirow{2}{*}{$\begin{array}{l}\text { Assimilation } \\
\text { efficiency }\end{array}$} & \multirow{2}{*}{ pro. met1. met2 } & Lower & $\begin{array}{l}\text { Assimilation efficiency of zooplankton is at least } 50 \% \text { of their total } \\
\text { ingestion }\end{array}$ & $50 \% \Sigma$ Ing $<$ Ing -det & L. C and B & \multirow{2}{*}{ Vézina et al. (2000) } \\
\hline & & Upper & $\begin{array}{l}\text { Assimilation efficiency of zooplankton is no more than } 90 \% \text { of their } \\
\text { total ingestion }\end{array}$ & Ing - det $<90 \% \Sigma$ Ing & L. C and B & \\
\hline \multirow{2}{*}{ Detritus production } & \multirow{2}{*}{ pro. met1. met2 } & Lower & $\begin{array}{l}\text { Zooplankton det production(zooTOdet)is at least 5\% of their det } \\
\text { production and respiration (zooTOres)combined }\end{array}$ & $\begin{array}{l}5 \% \text { (zooTOdet + zooTOres) } \\
\text { <zooTOdet }\end{array}$ & L. C and B & \multirow{2}{*}{ Steinberg et al.(2000) } \\
\hline & & Upper & $\begin{array}{l}\text { Zooplankton det production(zooTOdet)is no more than } 42 \% \text { of their } \\
\text { det production and respiration(zooTOres) combined }\end{array}$ & $\begin{array}{l}\text { zooTOdet }<42 \% \text { (zooTOdet }+ \\
\text { zooTOres) }\end{array}$ & L. C and B & \\
\hline Detritus dissolution & det & Upper & $\begin{array}{l}\text { Det dissolution(detTOdoc) does not exceed } 10 \% \text { of net primary } \\
\text { production(npp = gpp-r }-\mathrm{e} \text { ) }\end{array}$ & $10 \%($ gpp $-\mathrm{r}-\mathrm{e})<\operatorname{det}$ TOdoc & L. C and B & Pace et al. (1984) \\
\hline
\end{tabular}


87 Table 5. Flows values $\left(\mathrm{mgCm}^{-2} \mathrm{~d}^{-1}\right)$ estimated by the LIM-MCMC for each system. CI is the lower and higher $95 \%$ confidence interval 88 calculated from the probability distribution of each flow.

\begin{tabular}{|c|c|c|c|c|c|c|c|}
\hline & \multirow{2}{*}{\multicolumn{2}{|c|}{ Lagoon (inshore) }} & \multirow{2}{*}{\multicolumn{2}{|c|}{ Channel (inshore) }} & \multirow{2}{*}{\multicolumn{2}{|c|}{ Bay (offshore) }} \\
\hline & & & & & & & \\
\hline Flow description & Flow name & $\begin{array}{l}\text { Values } \\
\left(\mathrm{mgC} \mathrm{m}^{-2} \mathrm{~d}^{-1}\right)\end{array}$ & $\begin{array}{l}\text { CI } \\
\text { (low - high) } \\
\end{array}$ & $\begin{array}{l}\text { Values } \\
\left(\mathrm{mgC} \mathrm{m}^{-2} \mathrm{~d}^{-1}\right)\end{array}$ & $\begin{array}{l}\text { CI } \\
\text { (low - high) }\end{array}$ & $\begin{array}{l}\text { Values } \\
\left(\mathrm{mgC} \mathrm{m}^{-2} \mathrm{~d}^{-1}\right)\end{array}$ & $\begin{array}{l}\text { CI } \\
\text { (low - high) }\end{array}$ \\
\hline Microphyto.gross primary production & gpp-mic & 868.24 & $864.42-871.68$ & 795.25 & $795.21-795.28$ & 609.40 & $606.54-611.99$ \\
\hline Nanophyto. gross primary production & gpp-nan & 204.26 & $197.01-210.82$ & 65.44 & $64.12-66.63$ & 61.24 & $58.45-63.76$ \\
\hline Picophyto.gross primary production & gpp-pic & 161.74 & $153.56-167.66$ & 105.02 & $104.36-105.51$ & 56.21 & $54.4-57.47$ \\
\hline Microphyto.Respiration & mic-res & 45.24 & $43.52-48.03$ & 39.78 & $39.76-39.81$ & 31.81 & $30.54-33.89$ \\
\hline Microphyto. doc exudation & mic-doc & 76.48 & $74.78-79.13$ & 68.69 & $68.67-68.72$ & 53.73 & $52.46-55.69$ \\
\hline Microphyto. det production & mic-det & 267.01 & $152.41-432.34$ & 35.09 & $4.69-68.51$ & 142.78 & $23.78-245.56$ \\
\hline Microphyto. grazing by protozoooplankton & mic-pro & 349.23 & $177.58-452.94$ & 443.98 & $426.24-465.10$ & 325.94 & $223.04-444.93$ \\
\hline Microphyto. grazing by met1 & mic-met1 & 19.41 & $2.13-39.85$ & 33.49 & $18.93-45.04$ & 14.67 & $6.05-22.32$ \\
\hline Microphyto. grazing by met 2 & mic-met2 & 20.11 & $1.94-38.65$ & 65.55 & $49.75-79.40$ & 0.07 & $0.01-0.13$ \\
\hline Microphyto.Sinking & mic-los & 90.73 & $75.25-107.71$ & 108.65 & $87.66-141.48$ & 40.38 & $29.8-52.75$ \\
\hline Nanophyto.Respiration & nan-res & 13.63 & $10.42-18.85$ & 3.88 & $3.30-4.82$ & 4.31 & $3.13-6.26$ \\
\hline Nanophyto. doc exudation & nan-doc & 20.43 & $17.23-25.45$ & 6.15 & $5.57-7.04$ & 6.31 & $5.13-8.15$ \\
\hline Nanophyto. det production & nan-det & 59.6 & $27.53-92.45$ & 8.57 & $0.58-21.74$ & 6.77 & $0.63-14.57$ \\
\hline Nanophyto. grazing by protozooplankton & nan-pro & 71.71 & $56.04-86.84$ & 19.39 & $17.22-21.83$ & 35.73 & $31.71-40.69$ \\
\hline Nanophyto. grazing by met1 & nan-met1 & 18.39 & $1.71-38.31$ & 9.29 & $0.66-22.78$ & 6.83 & $0.64-14.6$ \\
\hline Nanophyto. grazing by met 2 & nan-met2 & 20.12 & $1.86-38.62$ & 9.32 & $0.67-22.8$ & 0.07 & $0.01-0.13$ \\
\hline Nanophyto.Sinking & nan-los & 0.35 & $0.34-0.35$ & 8.82 & $1.88-21.12$ & 1.21 & $0.97-1.44$ \\
\hline Picophyto.Respiration & pic-res & 13.24 & $8.37-20.48$ & 5.66 & $5.27-6.24$ & 4.10 & $2.87-5.86$ \\
\hline Picophyto. doc exudation & pic-doc & 18.28 & $13.43-25.32$ & 9.41 & $9.02-9.97$ & 5.91 & $4.71-7.63$ \\
\hline Picophyto. grazing by protozooplankton & pic-pro & 130.21 & $126.5-134.53$ & 89.94 & $89.63-90.33$ & 46.20 & $45.95-46.46$ \\
\hline Protozooplankton respiration & pro-res & 165.16 & $106.61-237.71$ & 181.34 & $134.88-242.87$ & 126.87 & $84.04-182.45$ \\
\hline Protozooplankton doc excretion & pro-doc & 88.79 & $52.99-135.09$ & 94.52 & $63.56-140.79$ & 66.38 & $39.20-104.71$ \\
\hline Protozooplankton det production & pro-det & 82.55 & $50.72-122.83$ & 94.01 & $64.91-131.28$ & 63.94 & $39.22-97.14$ \\
\hline
\end{tabular}


ACCEPTED MANUSCRIPT

\begin{tabular}{|c|c|c|c|c|c|c|c|}
\hline \multirow{2}{*}{$\begin{array}{l}\text { Protozooplankton uptake by met } 1 \\
\text { Protozooplankton uptake by met } 2\end{array}$} & pro-met1 & 118.95 & $12.66-256.34$ & 157.79 & $38.98-263.89$ & 98.84 & $15.11-189.53$ \\
\hline & pro-met2 & 107.85 & $7.58-245.02$ & 83.86 & $6.25-200.26$ & 65.94 & $5.69-150.92$ \\
\hline \multirow{2}{*}{$\begin{array}{l}\text { Met1 respiration } \\
\text { Met1 doc excretion }\end{array}$} & met1-res & 115.70 & $56.14-181.80$ & 92.34 & $48.28-146.04$ & 79.72 & $40.73-127.42$ \\
\hline & met1-doc & 62.01 & $27.35-115.34$ & 47.45 & $22.89-81.53$ & 40.80 & $19.25-70.45$ \\
\hline Met1 det production & met1-det & 56.63 & $25.89-96.04$ & 45.28 & $21.94-77.05$ & 38.71 & $18.46-66.52$ \\
\hline Met 1 uptake by met 2 & met1-met2 & 89.42 & $11.45-175.89$ & 67.21 & $8.93-140.26$ & 60.04 & $8.45-125.91$ \\
\hline Met1 sinking & met1-los & 46.56 & $3.18-120.59$ & 37.54 & $2.60-94.11$ & 31.28 & $2.13-79.26$ \\
\hline Met2 respiration & met2-res & 131.1 & $75.55-196.34$ & 95.73 & $54.75-145.23$ & 68.21 & $34.96-109.23$ \\
\hline \multirow{2}{*}{$\begin{array}{l}\text { Met } 2 \text { doc excretion } \\
\text { Met } 2 \text { det production }\end{array}$} & met2-doc & 67.58 & $34.65-110.93$ & 48.24 & $24.87-81.31$ & 34.57 & $16.19-60.42$ \\
\hline & met2-det & 64.76 & $33.51-106.25$ & 46.45 & $24.2-77.15$ & 32.37 & $15.43-55.99$ \\
\hline Met2 sinking & met2-los & 144.73 & $79.14-235.46$ & 96.31 & $56.03-147.49$ & 68.80 & $35.66-110.56$ \\
\hline \multirow{3}{*}{$\begin{array}{l}\text { Bacterial respiration } \\
\text { Bacterial doc release } \\
\text { Bacterial uptake by protozooplankton }\end{array}$} & bac-res & 9.06 & $7.07-11.73$ & 26.28 & $23.62-28.93$ & 13.24 & $7.66-19.59$ \\
\hline & bac-doc & 13.28 & $9.84-17.32$ & 32.18 & $29.52-34.83$ & 20.56 & $10.62-29.61$ \\
\hline & bac-pro & 12.15 & $8.79-16.39$ & 58.21 & $58.09-58.37$ & 14.11 & $12.83-15.44$ \\
\hline \multirow{2}{*}{$\begin{array}{l}\text { Dissolved organic carbon uptake by bacteria } \\
\text { Dissolved organic carbon output }\end{array}$} & doc-bac & 34.50 & $32.99-35.89$ & 116.67 & $116.34-116.9$ & 47.92 & $32.89-58.57$ \\
\hline & doc-los & 387.89 & $328.26-453.17$ & 235.60 & $182.6-292.65$ & 223.11 & $183.65-266.13$ \\
\hline \multirow{2}{*}{$\begin{array}{l}\text { Det dissolution } \\
\text { Det consumption by met1 }\end{array}$} & det-doc & 75.52 & $50.64-101.21$ & 45.60 & $23.61-76.42$ & 42.73 & $25.04-59.61$ \\
\hline & det-met1 & 213.57 & $46.21-382.11$ & 89.27 & $10.68-183.47$ & 130.23 & $20.46-258.34$ \\
\hline Det consumption by met 2 & det-met2 & 170.66 & $12.26-336.69$ & 60.79 & $4.49-148.01$ & 77.83 & $6.43-185.02$ \\
\hline Det sinking & det-los & 70.80 & $4.26-195.68$ & 33.74 & $1.96-93.32$ & 33.77 & $1.94-96.4$ \\
\hline
\end{tabular}


Table 6.Results of Cliffs' $\delta$ test applied to ecological network indices calculated for the Lagoon, the Channel and the Bay(a, Lagoon-Channel; b, Channel-Bay; c, Lagoon-Bay comparison). Significant level at Cliffs' $\boldsymbol{\delta}>-/+0.9$.

Between brackets, the magnitude of the effect (S: small, M: medium and L: large).

\begin{tabular}{lclc} 
& a- Lagoon-Channel & b- Channel-Bay & c- Lagoon-Bay \\
\cline { 2 - 4 } TST & $0.30(\mathrm{~S})$ & $0.37(\mathrm{M})$ & $0.62(\mathrm{~L})$ \\
A & $-0.99(\mathrm{~L})$ & $-0.99(\mathrm{~L})$ & $-1.00(\mathrm{~L})$ \\
DC & $-0.99(\mathrm{~L})$ & $-0.99(\mathrm{~L})$ & $-1.00(\mathrm{~L})$ \\
A/DC & $0.20(\mathrm{~S})$ & $0.90(\mathrm{~L})$ & $0.90(\mathrm{~L})$ \\
APL & $-0.91(\mathrm{~L})$ & $-0.97(\mathrm{~L})$ & $-0.99(\mathrm{~L})$ \\
FCI & $0.91(\mathrm{~L})$ & $-0.41(\mathrm{M})$ & $0.51(\mathrm{~L})$ \\
\hline
\end{tabular}




\section{Highlights for reviewer}

Herbivorous and multivorous food-webs were the dominant carbon pathways in the Bay and the Lagoon/Channel, respectively during the study period.

Indices used, showed that the Lagoon and the Channel seemed to be more stressed, more active, and less organized compared to the Bay of Bizerte

Inverse modelling combined with ecological networks analysis may offer an effective tool for management and assessment of ecosystems health, and to diagnose the occurrence of anthropogenic pressures. 